NBER WORKING PAPER SERIES

RECENT RESEARCH ON THE ECONOMICS OF PATENTS

\author{
Bronwyn H. Hall \\ Dietmar Harhoff \\ Working Paper 17773 \\ http://www.nber.org/papers/w17773
NATIONAL BUREAU OF ECONOMIC RESEARCH
1050 Massachusetts Avenue
Cambridge, MA 02138
January 2012

Forthcoming in the Annual Review of Economics doi: 10.1146/annurev-economics-080511-111008. No outside sources of research support were received during the writing of this paper. The views expressed herein are those of the authors and do not necessarily reflect the views of the National Bureau of Economic Research.

NBER working papers are circulated for discussion and comment purposes. They have not been peerreviewed or been subject to the review by the NBER Board of Directors that accompanies official NBER publications.

(C) 2012 by Bronwyn H. Hall and Dietmar Harhoff. All rights reserved. Short sections of text, not to exceed two paragraphs, may be quoted without explicit permission provided that full credit, including (C) notice, is given to the source. 
Recent Research on the Economics of Patents

Bronwyn H. Hall and Dietmar Harhoff

NBER Working Paper No. 17773

January 2012

JEL No. K11,L20,O34

\section{ABSTRACT}

Recent research on the economics of patents is surveyed. The topics covered include theoretical and empirical evidence on patents as an incentive for innovation, the effectiveness of patents for invention disclosure, patent valuation, and what we know about the design of patent systems. We also look at what is known about some current policy areas, including software and business method patents, university patenting, and the growth in patent litigation.

Bronwyn H. Hall

Dept. of Economics

549 Evans Hall

UC Berkeley

Berkeley, CA 94720-3880

and NBER

bhhall@nber.org

Dietmar Harhoff

Institute for Innovation Research

Munich School of Management

University of Munich

Kaulbachstrasse 45

D-80539 Munich, Germany

harhoff@bwl.uni-muenchen.de 


\section{Contents}

Recent Research on the Economics of Patents ....................................................................... 3

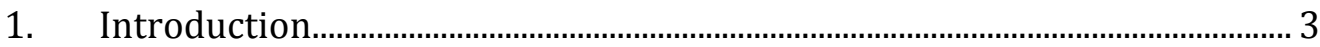

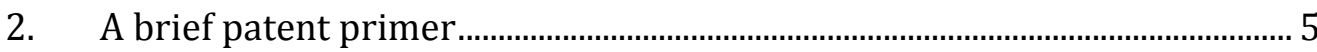

3. Are patents effective in inducing innovation?

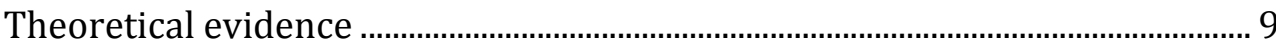

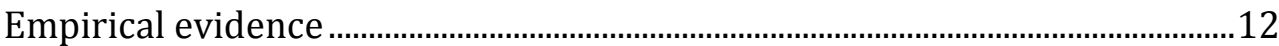

4. Are patents effective at inducing disclosure? ..................................................16

5. Valuing patents and their use in the market place .........................................18

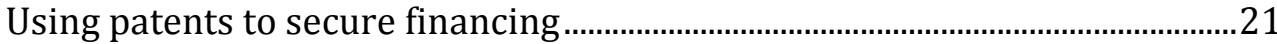

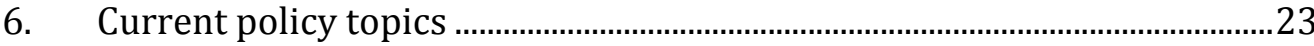

Software and business method patents ……….........................................................23

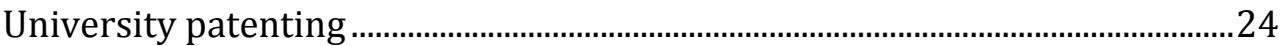

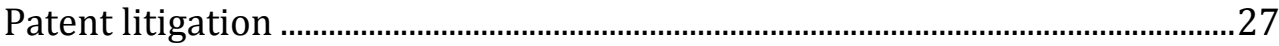

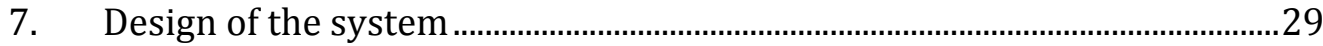

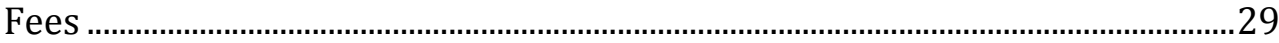

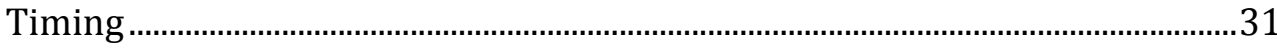

Post-grant review....................................................................................................

Patent office governance and human resource management ..............................34

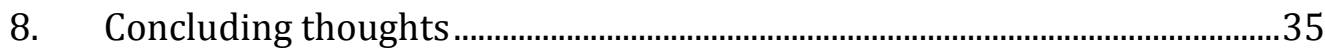

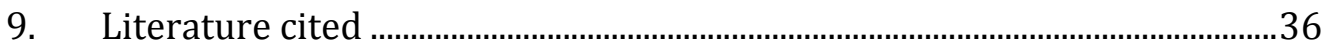




\title{
Recent Research on the Economics of Patents
}

\author{
Bronwyn H. Hall ${ }^{1}$ and Dietmar Harhoff ${ }^{2}$
}

August 2011

"If national patent laws did not exist, it would be difficult to make a conclusive case for introducing them; but the fact that they do exist shifts the burden of proof and it is equally difficult to make a really conclusive case for abolishing them." 3

\section{Introduction}

The rise of the knowledge economy has been accompanied, inter alia, by a large increase in the volume of research devoted to the economics of patents and the patent system. The growth in research reflects the increased economic importance of the property rights attached to the production and commercialization of new ideas. This article provides an entry point into that research by describing the basic features of a patent and patent systems and then reviewing the wide range of research on the topic, with an emphasis on more recent work. ${ }^{4}$

Simply stated, when the government grants a patent, it trades off short term exclusive (monopoly) rights to the use of an invention in return for two things: 1) an incentive to create the invention in the first place and 2) early publication of the invention rather than the use of secrecy to protect its misappropriation. But with the increasing importance of investment in knowledge and the accompanying increase in the use of the patent system, it has become apparent that things are far more complex than that simple tradeoff would suggest.

The first observation is that invention is cumulative, with each discovery today building on discoveries in the past. Therefore the incentive created for one invention or innovation via the patent right can act to slow down or increase the cost of a subsequent invention that builds on the first. This fact suggests that the overall effect on innovation

\footnotetext{
${ }^{1}$ University of Maastricht and University of California at Berkeley. NBER and IFS London.

${ }^{2}$ Ludwig-Maximilians Universität München and CEPR.

${ }^{3}$ Penrose (1951), p. 40.

${ }^{4}$ Although we have included work based on data from other countries, the work surveyed here is inevitably somewhat U.S.-focused, because the majority of the research in this area to date has either used U.S. data or has been instigated by questions of U.S. patent policy.
} 
may not be as strong as would be suggested by the tradeoff given above. The second observation is that firms and individuals that are endowed with such a rather complex legal instrument will learn to use it strategically in ways that may not serve the intent of the legislation that created the instrument. For example, the benefits of publication may be limited by careful drafting of the patent or the omission of essential (tacit) knowhow. Or a patent may be taken out and then kept "sleeping" solely to disadvantage a competitor and to preserve a (temporary) monopoly in a particular market.

A final observation is that knowledge-intensive firms face a number of problems associated with the fact that their assets are largely intangible and patents can help to mitigate these problems. In particular, clear title to at least some of these assets facilitates obtaining financing, at least from those willing to provide risk capital such as venture capitalists. In principle, the existence of secondary markets for patent assets, which are still in their infancy (Ocean Tomo, Yet2, Intellectual Ventures, etc.), should facilitate entry into knowledge-intensive sectors, by increasing the salvage value of a firm that ultimately fails. Patents can also serve as a focusing device for the trading of expertise and know-how between firms. They have the advantage that they are legal documents which define the boundaries of the covered technology and are therefore easily incorporated into other legal documents such as licensing contracts. ${ }^{5}$

Recent research on the economics of patents has concentrated on the topics suggested by the foregoing observations and on topics related to current "hot-button" policy questions. These latter include the expansion of patentable subject matter (specifically, software, business methods, and genomic material), the apparent increase in litigation and patent holdup, increased patenting activity by universities following the Bayh-Dole Act of 1980 and its equivalents in other countries, and various questions related to patent system reform, especially in the light of the worldwide increase in patent applications that we have experienced during the past 20 years (Fink et al. 2011).

We begin with a brief introduction to patent systems and their rationale. This is followed by a review of the theoretical and empirical evidence on the effectiveness of patents in encouraging invention. We then discuss the disclosure aspect of patenting and recent research that attempts to assess how well patents serve the purpose of revealing technological information to others. This is followed by a brief review of the recent research related to current policy questions. Finally, we spend some time on research addressed to the design of patent systems: how can they be improved, and what is the evidence that such improvements might be effective?

\footnotetext{
${ }^{5}$ However, see Bessen and Meurer (2009) for an extensive discussion of the limitations of some patents as a well-defined property right.
} 
In a survey of this length on such a large topic, it has not been possible to cover every subarea of interest. Fortunately, there are other excellent surveys available on some of the topics we have omitted. We mention two of the most important here. The first is the role of patents in technology transfer and economic development, a topic which has taken on increased importance with the adoption of TRIPS (Trade-Related aspects of Intellectual Property rights) in a large number of countries. Here we can point the reader to several useful surveys: Branstetter (2004), Hall and Helmers (2010), Maskus (2004), and a summary report by ICSTD and UNCTAD (2003).

The second topic we have overlooked is that of the use of patents in economic research as indicators or proxies for the underlying knowledge creation. Here it is hard to replace the excellent survey by Griliches (1990), which although it was written over two decades ago, covers the area very well. If we have learned anything since about using patents as indicators, it is that correct interpretation of the results of such use requires a good understanding of the changes in patent law, firm strategy, and the heterogeneity of industries and technologies, something to which we hope the current survey will contribute.

\section{A brief patent primer 6}

Patents have a long history, although some of the earliest patents are simply the grant of a legal monopoly in a particular good rather than protection of an invention from imitation. Early examples of technology-related patents are Brunelleschi's patent on a boat designed to carry marble up the Arno River, issued by the Florentine government in 1421 (Prager 1946), the Venetian patent law of 1474, and various patent monopolies granted by the English crown between the 15th and 17th centuries. The modern patent, which requires a working model or written description of an invention, dates from the 18th century, first in Britain (1718) and then in the United States (1790), followed closely by France (in both the latter two cases one of the consequences of a revolution). ${ }^{7}$ Many other Continental European countries introduced patents during the 19th century, as did Japan (JPO, 2006) and India (James, 2007). During the 20th century, the use of patent systems became almost universal and the signing of the TRIPS agreement has ensured that all countries who are members of the World Trade Organization will have at least a minimal level of patent protection.

In 1883 the Paris Convention for the Protection of Industrial Property guaranteed national treatment of patent applicants from any country that was a party to it. Its most important provision gave applicants who were nationals or residents of one member state the right to file an application in their own country and then, as long as an

\footnotetext{
${ }^{6}$ Some of the material in this section is drawn from Hall (2007).

${ }^{7}$ Ladas and Parry (2003). See also the EPO and USPTO websites (EPO, 2007a and USPTO, 2007).
} 
application was filed in another country that was a member of the treaty within a specified time (now 12 months) to have the date of filing in the home country count as the effective filing date in that other country (the 'priority date'). This is an important feature of the patent system, as it enables worldwide priority to be obtained for an invention originating in any one country, in addition to ensuring that in principle all inventors are treated equally by the system, regardless of the country from which they come.

Although the process for granting a patent varies slightly according to the jurisdiction for which protection is desired, the adoption of the TRIPS agreement in 1995 ensures that it is approximately the same everywhere in the world. This agreement requires its member countries to make patent protection available for any product or process invention in any field of technology with only a few specified exceptions. It also requires them to make the term of protection available for not less than a period of 20 years from the date of filing the patent application. As of July 2011, 148 countries are signatories to this agreement and 31 countries (mostly members of the former USSR) are designated as "observers."

The World Intellectual Property Organization (WIPO) has almost 200 member states and lists an equivalent number of national patent offices and industrial property offices on its website. In general, the patent right extends only within the border of the jurisdiction that has granted it (usually but not always a country). An important exception to this rule is the European system, where it is possible to file a patent application at the European Patent Office (EPO) that will become a set of national patent rights in several European countries at the time of issue (EPO, 2006). A similar situation exists with respect to the African Regional Intellectual Property Organization (ARIPO). The exact number and choice of countries is under control of the applicant. Patents granted by the EPO have the same legal status as patents granted by the various national offices that are party to the European Patent Convention (EPC).

The Patent Cooperation Treaty (PCT) came into existence in 1978, and now has 145 countries as contracting signatories. Any resident or national of a contracting state of the PCT may file an international application under the PCT that specifies the office which should conduct the search. The PCT application serves as an application filed in each designated contracting state. However, in order to obtain patent protection in a particular state, a patent needs to be granted by that state to the claimed invention contained in the international application. The advantage of a PCT application is that fewer searches need to be conducted and the process is therefore less expensive. Thus, although application and search are to some extent standardized across offices, grants are not. In fact, 87 per cent of the PCT applications go to one of three patent offices for search: those in the United States, Europe, and Japan (WIPO 2007). Most of the other systems rely on them for the search process and follow them in a number of other areas. 
Many patent offices have a provision for challenging patents following their issue. In the United States, any third party may request re-examination of a patent during its lifetime. For various reasons related to potential subsequent litigation this opportunity has been taken up rarely in the past although recently the use of reexamination requests in conjunction with litigation appears to have increased. ${ }^{8}$ In Europe and Japan, robust patent opposition systems with limited time frames operate, and these systems are often used by rival firms as an alternative to more expensive litigation (Hall et al., 2003; Harhoff and Reitzig 2004). In Europe this avenue of challenge is particularly attractive because it is the last opportunity to attack the validity of a patent at the European-wide level rather than in individual national courts.

Patents are valuable only if they can be enforced and this fact has a number of implications for their use. First, the ability of the courts to reach the 'correct' verdict with respect to infringement and validity will matter; in situations or jurisdictions where there is a great deal of uncertainty about the outcome, and even if both parties agree as to the merits of the case, it may be worthwhile for one or both of them to pursue the issue further or in some cases, to reach a private financial settlement to avoid a random outcome in the courts. ${ }^{9}$ Second, the costs of litigation will matter: parties with deep pockets can threaten those with less access to financial resources, or where the opportunity cost of paying attention to a patent suit is high, as in small entrepreneurial firms. On the other hand, smaller parties with little to lose can also hold up firms with large sunk investments at risk (Hall and Ziedonis 2001, Lemley and Shapiro 2007, Shapiro 2010). Finally, the threat of litigation may discourage firms from even entering certain areas, thus providing a disincentive rather than an incentive for R\&D. Lerner (1995) documented this phenomenon for biotechnology.

The degree to which these kinds of threats matter depends to a great extent on the costs and extent of litigation, both of which tend to be higher in the United States than in many other countries. However, there are signs that concerns about litigation cost have been increasing elsewhere, notably in Europe where there is active debate over proposals to reduce enforcement costs by creating a supranational patent court system of some kind. At the time of writing, the current proposal, which is the European Patent Litigation Agreement (EPLA), has not yet been ratified by enough countries to make it legally binding, and there exists a new proposal for a unitary European patent. See EPO (2007b) for the current state of all legislative initiatives in Europe.

\footnotetext{
${ }^{8}$ Users of this procedure are estopped from raising any issues of validity that might have been raised in re-examination in subsequent litigation. In practice, less than one per cent of U.S. patents are re-examined, and almost half of those re-exams are requested by the patentholder or the USPTO itself (Graham et al., 2003). Recently the number of re-exams requested by third parties has been rising slightly and there is evidence that this procedure is now part of the arsenal used by potential infringers when defending against a patentholder (D. Crouch, Patently-O website, 5 June 2008).

${ }^{9}$ See Farrell and Shapiro (2007) for detailed models of this process.
} 


\section{Are patents effective in inducing innovation?}

The economic view of patents is that they offer a bargain between society and the inventor: in return for a limited period of exclusivity, the inventor agrees to make his invention public rather than keeping it secret. Two questions immediately arise from this: first, what is the optimal design of such a policy instrument? And second, are patents effective at accomplishing this task? This section of the article looks at the second question - how effective are patents at inducing innovation? A later section will look more closely at the related question of how to improve patent system design.

Table 1 presents a framework for thinking about the costs and benefits of the patent system in two dimensions, innovation and competition, a framework that reflects some of the things economists have learned about the operation of patent systems in practice during the past twenty or so years. The on-diagonal boxes represent the traditional tradeoff between negative effects for competition arising from market power and the positive effects for innovation, while the shaded off-diagonals represent the ways in which patents might actually discourage innovation but enable and encourage competition.

Table 1

The Patent System Tradeoffs

\begin{tabular}{|l|l|l|}
\hline Effects on: & Benefit & Cost \\
\hline Innovation & $\begin{array}{l}\text { creates an incentive for R\&D; } \\
\text { promotes the diffusion of } \\
\text { ideas }\end{array}$ & $\begin{array}{l}\text { impedes the combination of } \\
\text { new ideas \& inventions; raises } \\
\text { transaction costs }\end{array}$ \\
\hline Competition & $\begin{array}{l}\text { facilitates entry of new small } \\
\text { firms with limited assets; } \\
\text { allows trading of inventive } \\
\text { knowledge, markets for } \\
\text { technology }\end{array}$ & $\begin{array}{l}\text { creates short-term monopolies, } \\
\text { in network industries }\end{array}$ \\
\hline
\end{tabular}

This chart suggests that in addition to the familiar arguments that patents increase innovation via incentive effects and diffusion and decrease competition because they create temporary monopolies, there are offsetting effects in both cases, effects that have become more apparent in recent years. These offsetting effects are the tendency of patents to increase the costs of subsequent innovators, especially when these innovators need to combine inventions from many sources, as well as the fact that patents may help competition by facilitating the vertical disintegration of knowledge- 
intensive industries and helping new entrants. The next two sections of the article review the evidence, both theoretical and empirical, on the effectiveness of the current patent systems in achieving the goal of encouraging innovation without incurring too high a cost for competition.

\section{Theoretical evidence}

A voluminous theoretical literature addresses a range of questions about the workings and design of the patent system and the consequences of the system for firm strategy. Time and space will prevent us from supplying an exhaustive review in this article. However, we are able to refer the reader who desires more information to two recent surveys of the topic, a handbook chapter by Rockett (2010) and an advanced text by Scotchmer (2005), as well as an excellent non-technical review of the literature on the choice of incentives for innovation by Gallini and Scotchmer (2002). In addition, there is an earlier handbook chapter by Reinganum (1989) that reviews the first wave of the literature on patent races and innovation timing. In our review here we focus on what the most recent literature has to say about the effectiveness of patents in promoting innovation.

As is often the case with models that admit the complexity of the world, the theoretical literature addressed to this question produces ambiguous results with respect to incentives provided by patents. In the simplest case, where a patent corresponds to a single product and knowledge is not particularly cumulative, it is clear that patents will encourage innovation. Offering individuals the short-term right to exclude others from practicing an invention provides them with the opportunity to earn rents or supranormal profits when they innovate that are higher than those they would earn if there were immediate free entry into imitation of their invention. The early theoretical industrial organization literature on patent races even seemed to suggest that patents produced too much innovation when there was free entry into invention (Wright, 1983; Reinganum, 1989).

However, it is also immediately clear that the simple case ignores at least two realities: 1) invention is cumulative and the knowledge covered by a patent is frequently an input into further invention and patenting; 2) most products are covered by multiple patents and these patents may be held by more than one entity. These two facts greatly complicate both the design of an optimal patent system and the expected effects of any patent system on innovation. In the case of cumulative invention, the literature has considered two main cases and their variations: in the first (at least) two innovative stages are required to produce the product (the "research tool" case) and in the second there is a sequence of products each of which is an improvement over the previous product (the cumulative or "quality ladder" case). In either case, it is possible that any particular invention uses one or more other inventions as input or is an input to one or more future inventions. 


\section{Cumulative invention}

As first pointed out by Scotchmer (1991), in the case of sequential invention where one invention builds on another, and only the second generates a product that can be priced in the market, it is impossible to set up a decentralized incentive system using patents that guarantees the first best level of innovative activity by both inventors, essentially because of a double marginalization problem. The only solution that is able to do this is an ex ante contract between first and second inventor before R\&D is sunk by either of them. But this solution is obviously difficult to implement most of the time, because the first inventor is unable to identify the second inventor at the time he is prepared to sink R\&D costs nor is there full information on the value of either the second or the first invention.

In their review of the literature, Gallini and Scotchmer (2002) emphasize the fact that licensing contracts will often solve problems arising from disjoint ownership of complementary knowledge inputs. At the same time, fluid contracting (to use their term) may lead to anti-competitive behavior and therefore antitrust concerns, especially in the case of cross-licensing and patent pools. Maurer and Scotchmer (2006) propose a set of acceptable licensing terms that could be used for per se enforcement in this case (although their use would seem to involve some rule of reason). Lerner and Tirole (2004) offer a thorough welfare analysis of patent pools and are able to show that a pool is never affected by the possibility of that a member can license one or more patents independently if and only if the pool is welfare-enhancing. This suggests a way to ensure that only welfare-enhancing patent pools are allowed.

Several recent papers use models of cumulative innovation to examine the welfare impact of the patent system and its design. An influential paper by Bessen and Maskin (2006) develops a model of sequential (cumulative) and complementary innovation in a differentiated product setting and analyzes the effect of patent protection in two settings, nonsequential and infinitely sequential (that is, where each invention builds on the preceding invention). The results are somewhat complex but intuitive: in the static nonsequential case, having patents generally yields higher welfare than not having them, as in the one patent-one product case. But in the fully sequential case, the equilibrium without patents has higher welfare and innovation than the equilibrium with patents if the upper tail of the distribution of innovation values is sufficiently thick. They show that the two commonly used distributions for innovation value, lognormal and Pareto, satisfy this condition. ${ }^{10}$ They also show that in some cases, even the original innovator may benefit from the absence of patents in the dynamic case, because he receives spillovers from follow-on innovation. Empirical evidence that suggests some positive value to this kind of spillover has been offered recently by

\footnotetext{
${ }^{10}$ Later in this article we describe the evidence that these two distributions are a reasonable characterization of the distribution of returns to innovation.
} 
Belenzon (2006) using sequences of patent citations to measure knowledge flows in and out of the firm.

O’Donoghue et al. (1998) introduced the concepts of "effective patent life", which is the time until a new innovation displaces the current one, "lagging breadth" (which protects against inferior products), and "leading breadth" (the minimum quality improvement that avoids infringement). They show that lagging breadth may not provide sufficient incentives for R\&D. Using a simple model of the exogenous arrival of ideas at each firm, which may or may not be taken up, they show that with finite but very broad patents, the diffusion of new products is encouraged, but with long and narrow patents, there are lower R\&D costs. Either choice can attain a specified level of innovation. O'Donoghue (1998) uses a similar quality ladder model of patented innovations of various inventive steps, but where the size of the step is chosen by the innovator, to examine how a patentability requirement (leading and lagging breadth of the patent) and patent life affect the level of innovation. In his model, by using a patentability requirement (minimum inventive step) one can get the optimal level of $R \& D$ investment by extending the effective patent life.

Using a model similar to that of O'Donoghue et al. (1998), Hopenhayn et al. (2006) derive an optimal reward system for the cumulative innovation setting where idea quality and development cost are private information to the inventor. They show that an optimal patent menu can be implemented via licensing without knowledge of the licensee, by having each innovator commit to a price ceiling at which he will sell his rights to a future inventor.

\section{Fragmented invention}

The analysis of patent ownership fragmentation has increased in importance because of the complexity of modern technology and also because of growth in patent use in sectors that traditionally had regarded patent protection as relatively unimportant. Briefly described, the new setting is one where a single product involves accessing the technologies in hundreds of patents. This feature is really new, but it has assumed increasing importance in a number of technology areas such as information technology and biotechnology (Shapiro 2001). Unlike the case of cumulative innovation, in the absence of transaction costs the problems of fragmented innovation could in principle be solved by contracting over patent licenses, although there remains a bargaining problem given the presence of patent rents. Although the two cases are very similar, the essential difference is one of timing: fragmented innovation is assumed to be based on inventions made more or less simultaneously whereas cumulative innovation requires invention in sequential order.

However, when development of an innovative product requires multiple patent inputs, Heller and Eisenberg (1998) have argued forcefully that the licensing solution may fail because of transactions costs if a large number of patentholders are involved. 
One consequence of this fragmentation threat may be increased defensive patenting by the product developer in order to be able to threaten a countersuit if attacked. Empirical evidence for this proposition has been provided by Ziedonis (2004) in the context of the semiconductor industry. She shows that firms patent more aggressively when their patents draw on a more widely dispersed base of technology. An interesting recent paper by Galasso and Schankerman (2010) shows that in cases like this that rely on bargaining for profit division, settlement time among the patentholders is decreasing as their numbers increase holding complementarity among the patented inventions constant and nonincreasing in complementarity holding the number of patentholders constant. They find support for these assertions in U.S. patent litigation data.

Denicolo and Halmenschlager (2010) build a model of fragmented IP rights where the patent office commits both Type I and Type II errors when granting patents and there is a free entry equilibrium. Two complementary innovations are needed for a product; if only one is patentable, the firm that owns it controls the technology and obtains all the profits. They show that under fragmentation of ownership and uncertainty over patentability, fewer and stronger patents are needed for the social welfare optimum, which is a plausible conclusion.

Hunt (2006) presents a model of R\&D competition with overlapping patents, where the firms involved capture some of the rents from their competitor's R\&D and patenting activities. He shows that if the overlap is strong enough (because of the density of patenting, because of spillovers, or simply because the patent office has made errors in issuing patents on obvious inventions), the effect of patents is to reduce rather than increase the incentive of R\&D investment. Hunt (2004) contains a dynamic version of this model, which reaches much the same conclusion.

\section{Empirical evidence}

It is fair to say that the theoretical work surveyed above does not deliver a clear message about the effectiveness of the patent system in encouraging innovation, although it does supply interesting insights into which design features are of interest and could be used to tune the system. For evidence on the effectiveness of patents in general in encouraging innovation, we turn to the empirical evidence.

Unfortunately, the question has also proved difficult to answer empirically, largely because of the absence of real experiments, at least since the nineteenth century. Some researchers have looked at historical eras when there were changes to the system and examined the consequences for subsequent innovative activity, measured either by patenting in a jurisdiction not affected by the changes to the system or by invention counts obtained independently. Using aggregate data from 1850 to 2000, Lerner (2002) found that domestic patenting both at home or in Great Britain fell when the patent system was strengthened, although patenting by foreign firms rose. Moser (2005) constructed a dataset of 15,000 innovations from a number of European countries that 
were displayed at two international fairs during the $19^{\text {th }}$ century, and found that although the level of innovative activity in these countries was unaffected by the presence of a patent system, in countries without such a system innovation tended to be concentrated in sectors where secrecy was a useful protection mechanism.

A particularly interesting example from the $19^{\text {th }}$ century is the emergence of industrial leadership in artificial dyestuffs. While England was initially the leading manufacturer of artificial dyes after the first invention (aniline purple, which was later called mauve in France) had been made by Perkin in 1856, the chemical industry in Germany became dominant by 1880 and extended this lead up to the years before the First World War The size of the market, the availability of finance, and access to end markets should all have favored England, hence the reversal occurred against the odds.

The role that patents had in this development is contested. Boldrin and Levine (2008) argue that the case of the dyestuff industry bolsters their call for an outright abolition of patents: Germany only adopted a comprehensive patent system in 1877, and patent protection then granted was weak as only processes, but not products were covered. However, the most detailed study of this development by Murmann (2003) is considerably more nuanced in its assessment. In Murmann's assessment, the dominant factor in the ascendancy of German producers was the evolution of close cooperation between academic research in universities and the emerging R\&D laboratories in the German chemical industry. He also argues that collective action by industry, academe, and policy-makers strengthened the position of German producers by bringing targeted reform to the German patent system. ${ }^{11}$ Moreover, he credits patent laws with a positive role in German dominance: "Even if there had been no patent protection in any of the three countries, Germany would have outperformed the British and American dye industries. But without patents in Germany and in other large dye markets, the German dye industry would not have been able to acquire a virtual monopoly."12

Our reading of the historical episode is that the German patent system allowed for a much better balance between competition and innovation than its British and French counterparts: patent system design matters, and more restrictive patent systems with strong examination standards may be superior to those with weak quality standards. Moreover, policy-makers in Germany were apparently willing to shape patent laws in the favor of a particular industry. This is reminiscent of the ways in which many developing countries in East Asia have tailored their patent systems to their level of development, introducing full protection at the levels in developed countries only late in their development.

\footnotetext{
${ }^{11}$ Murmann (2003), p. 5.

${ }^{12}$ Murmann (2003), p. 179.
} 
A second widely used approach to the empirical analysis of patent effectiveness is to survey firm managers, asking about their own patent use and the use of patents in their industry (Mansfield, 1986; Levin et al., 1987; Cohen et al., 2002; Arundel, 2003). Using these kinds of survey data matched to R\&D spending and innovation outcomes, Baldwin, Hanel and Sabourin (2000), Arora, Ceccagnoli and Cohen (2003) and Bloom, Van Reenen and Schankerman (2007), among others, have pursued estimation strategies based on econometric modeling.

A few conclusions have emerged from this body of work. First, introducing or strengthening a patent system (lengthening the patent term, broadening subject matter coverage or available scope, improving enforcement) unambiguously results in an increase in patenting and also in the use of patents as a tool of firm strategy (Lerner, 2002; Hall and Ziedonis, 2001). This is to be expected, but it is much less clear that these changes result in an increase in innovative activity (Lerner 2002; Baldwin et al., 2000), although they may redirect such activity toward things that are patentable and away from those than can be kept secret within the firm (Moser, 2005). Sakakibara and Branstetter (2001) studied the effects of expanding patent scope by allowing multiple claims in Japan in 1988 and found that this change to the patent system had a very small effect on R\&D activity in Japanese firms.

An exception to this conclusion are two studies based on cross country data: Park and Ginarte (1997) and Kanwar and Evenson (2003). Park and Ginarte (1997) uses aggregate data for 60 countries during from 1960-1990 and an index of the strength of IP rights (subject matter coverage, term length, etc.) which they developed and which has since been widely used in the literature. Using a simultaneous equations model of economic growth, investment, schooling, and R\&D investment, they found that the strength of IP rights was positively associated with investment and R\&D investment in countries with above median income but not for the less-developed countries. IP rights had no independent effect on growth above and beyond that contributed by investment and R\&D. However, Park and Ginarte (1997) also shows that the strength of IP rights in high income countries (but not in low income countries) can be predicted by prior R\&D intensity, which raises some questions about the simultaneity of IP protection and a country's orientation towards R\&D and innovation. That is, it is possible that the demand for IP protection increases when a large share of the industrial base is engaged in innovative activities.

The study by Kanwar and Evenson (2003) looks at the variation across country in R\&D spending as a function of the Ginarte-Park index over the 1981-1995 period and finds similar results, with stronger IP protection related to higher R\&D intensity. Although well done in many respects, this study makes no attempt to explore the potential endogeneity of the relationship nor does it control for the level of development of the countries, which arguably drives both R\&D and the development of IP institutions. 
In contrast to the two results cited above, Qian (2007) performs a similar analysis for pharmaceutical patents in 85 countries over the 1978-1999 period, but using matched sampling and also fixed country effect estimators in a serious attempt to control for the simultaneity between levels of IP protection and R\&D intensity at the country level. She finds that national patent protection does not stimulate domestic innovation activities, except at higher development levels, and that above a certain level of patent protection, innovation activities are actually reduced.

A third finding from the empirical literature is that if there is an increase in innovation due to patents, it is likely to be centered in the pharmaceutical, biotechnology, and medical instrument areas, and possibly specialty chemicals. This conclusion relies mostly on survey evidence from a number of countries which shows rather conclusively that patents are not among the important means to appropriate returns to innovation, except perhaps in pharmaceuticals, medical devices, and some specialty chemicals (Mansfield, 1986; Levin et al., 1987; Cohen et al., 2001; Arora et al., 2001; Graham et al., 2009). Using a structural model that combines survey responses with accounting data on R\&D, Arora, Ceccagnoli and Cohen (2003) found that increasing the patent premium, which they define as the difference in payoffs to patented and unpatented inventions, can be expected to increase R\&D in most manufacturing sectors, with the greatest increase in medical instruments, followed by biotechnology and pharmaceuticals.

Fourth and finally, the existence and strength of the patent system affects the organization of industry, by allowing trade in knowledge, which facilitates the vertical disintegration of knowledge-based industries and the entry of new firms that possess only intangible assets (Hall and Ziedonis 2001; Arora et al 2003; Arora and Merges 2004). The argument is that, by creating a strong property right for the intangible asset, the patent system enables activities that formerly had to be kept within the firm because of secrecy and contracting problems to move out into separate entities.

Although limited, research in this area supports this conclusion in the chemical and semiconductor industries. Later in this article we discuss the role of patents in obtaining financing for new knowledge-intensive firms.

The bottom line from the empirical evidence is that the patent system provides clear incentives for innovation in only a few sectors, but that firms and industries do respond to its presence, both by making use of the system and by sometimes tailoring their innovative strategies to its presence. One possible interpretation of the quote from Edith Penrose at the beginning of this article is that history matters, in the sense that industrial organization and firms adapt themselves to the institutional regime in which they find themselves and that changing this regime, whatever it is, involves substantial short term costs that may not be outweighed by the long term benefits. 


\section{Are patents effective at inducing disclosure?}

The notion that the patent literature facilitates follow-on inventions is widespread. As we discussed in the introduction, the patent system is often portrayed as a contract between inventors (respectively patent-holders) and society. Inventors receive a valuable exclusion right in exchange for their inventive efforts, and society receives valuable information that allows follow-on inventor to improve upon the invention. Machlup and Penrose (1950) are an early example of this tradition and state their presumption that patents help to disseminate technical information, which in turn supports productivity growth. The argument is repeated in other contributions, such as Landes and Posner (2003), Kitch (1977), Menell (2000). Discussions from an economic point of view have been provided, inter alia, by Dam (1994), Mazzoleni and Nelson (1998) and Scherer (2002, 2010). In formal economic models of the patent system, disclosure is usually assumed to have a strong impact on follow-on inventors and cumulative invention processes (Scotchmer 1990, Scotchmer and Green 1990, Denicolo and Franzoni 2003). To date there is little empirical evidence as to what extent disclosure occurs and what its impact is in economic terms.

Disclosure assumes major importance in IP law: in almost all patent systems, insufficient disclosure of the invention can lead to revocation of a patent right or the rejection of an application. In the legal reasoning of US courts, the disclosure argument has played a major role, and a number of legal doctrines are based on the notion that disclosure is highly relevant. In a detailed survey of the literature on patent disclosure, Roin (2007) lists a number of Supreme Court cases in this vein. Some court opinions place the disclosure function of the patent system even ahead of its incentive function (Roin, 2007:2011f.). Contrary to the courts, many legal scholars appear to be skeptical that disclosure has a strong effect - these scholars argue that disclosure effects are small for both institutional and practical reasons.

The first two related arguments supporting this view point to the conscious decision that inventors have to make. Typically, they will have to decide between trade secrecy and patenting. ${ }^{13}$ Patenting would appeal to an innovator if the invention can readily be reverse-engineered from the innovative product. But if that is the case, then patented products would simply reveal information irrespective of the patent document. Second, if inventors know that rivals would learn a lot from their disclosed patents, secrecy may become the more appealing option for protecting an invention or innovation (Levin et al. 1987, Moser 2011). To summarize, inventions that are patented will be revealed via product designs in the market. And those inventions which would generate considerable valuable information for third parties via the patent documents alone will be particularly unlikely to be patented. Presumably this leaves a small group

\footnotetext{
${ }^{13}$ For theoretical treatments of this choice, see Anton and Yao (2004), Bhattacharya and Guriev (2006), Denicolo and Franzoni (2004), and Encaoua and Lefouilli (2005).
} 
of technologies for which patent documents contain valuable information.

Pharmaceuticals are likely to be such a case since the product appears very late in the market due to extensive clinical testing. Hence, rivals may be able to learn important information from patent documents in these fields. Moreover, they may learn what inventions are already covered by patents so that they may be able to avoid duplicative efforts.

The latter argument does not pass muster, either, unless engineers and scientists are willing to study patent documents. Many US scholars argue that Willful Infringement Rules in the US create additional risks for inventors (and applicants) who use patent documents as sources of information (Lee and Cogswell 2004; Powers and Carlson 2001; Sterne et al. 2004; Moore 2004). To manage that risk it may become necessary to take additional precautions and prepare legal opinions that shield the inventor from willful infringement attacks. This risk is likely to force R\&D managers to stop using patent documents as information sources in the invention and innovation process. Patents may still be used in the IP clearing process at the end of the innovation process (Toffel 2004) - but at this point, they can neither have a dampening effect on duplication, nor can they generate positive spillover effects (Roin 2010: 2021f., FTC 2003: 29-31).

A final set of reasons why disclosure is unlikely to be effective lies in the timing and quality of disclosure (Seymore 2010, Fromer 2009). The US patent system still allows applicants to keep applications secret prior to grant - albeit at the expense of not seeking patent protection in foreign jurisdictions. Furthermore, applicants may deliberately seek to keep some crucial information out of the patent document, and they may be successful in doing so unless they are challenged by the examiner to fill the gaps. As long as the likelihood of seeing the patent revoked is small (e.g., due to a lack of functional post-grant reviews) the incentive to do so will be relatively high. Finally, by developing complex claims construction rules, courts may have forced applicants to use legal language in their filings which are not conducive to clear transmission of scientific and engineering information (Roin 2007: 2023). Bessen and Meurer (2008: 8f.) support this view and point to a second effect that failing disclosure or notice has: the boundaries of intellectual property become "fuzzy", thus provoking more litigation among patent owners who are uncertain about the delineation of their rights.

So far, there have been few attempts to quantify the impact of patent literature and technical information from patents. Thus, neither the optimistic assessment by some courts nor the skeptical ones by legal scholars or economists can be confirmed. A paper by Gambardella et al. (2011) provides a first set of estimates of cost-savings incurred by follow-on inventors due to knowledge of the patent literature. The data were collected in a large-scale inventor survey covering more than 22,000 inventors in 23 countries. Inventors were asked for a qualitative assessment as to how important patents were as a source of information for a particular invention. Questions of this type 
have been used before in innovation surveys and - presumably for the first time - in the Yale Survey. Cohen et al. (2002) argue that US companies generally prefer other sources of information over patents. Moreover, Arora et al. (2008) find that these measures are not related to spillover effects which would favor productivity gains. Nagaoka and Walsh (2009) find large differences in the importance of patents between US and Japanese inventors. In line with the prior studies, Gambardella et al. (2011) find that patents are particularly important sources of information in a small number of technical areas, such as polymers, organic chemicals, pharmaceuticals, petrochemical and materials chemistry, and that Japanese inventors assign greater importance to information in patents than either European or US inventors.

More importantly, inventors were also asked in the survey described by Gambardella et al. (2011) to quantify the time saved for the respective invention process when compared to a situation in which the information from patents had not been available. Time savings from disclosures follow a highly skew distribution, with estimated median values of 5.9 hours and mean values of 12.2 hours. There is considerable heterogeneity across technical fields - median values range between 36 hours (organic chemicals) and 1.0 hours (digital communication technology). In fields where patents have strong impact on appropriability such as chemicals and pharmaceuticals, disclosure effects appear to matter the most.

As appealing as the disclosure argument is, this empirical analysis reinforces the notion that patents have highly heterogeneous effects, and that the incentive and the disclosure effects are strongly correlated. The overall social value of patent disclosures appears to be quite small in comparison to the private value of patents (Gambardella et al. 2011). Even if it were possible to "invigorate disclosure" (Fromer, 2009), total disclosure effects are likely to remain relatively small.

\section{Valuing patents and their use in the market place}

Many researchers have documented the increased importance of intangible assets relative to tangible assets in today's developed economies (Corrado et al. 2006; Hall 1993; RE Hall 2001; Haskel and Marrano 2007). The valuation of patents, as a form of property right on at least some of these assets, has therefore taken on increased importance. However, as emphasized by Schankerman and Pakes (1986) and Griliches (1990), there can be confusion over what we mean by the "value of a patent," even if we confine ourselves to private value, that is, the value to the patentholder. The patent itself has value as the right to exclude others from practicing the invention freely, but the possession of the patent also serves as a proxy for the value of the underlying invention, which may have private value even without the patent right (because of associated tacit knowhow, required complementary assets, and so forth). Harhoff et al. (2003) contains a useful discussion of the complexity of this issue. 
In general, work like Schankerman and Pakes or Hegde and Sampat (2009), to take a more recent example, which relies on patent renewals to estimate the value distribution is the closest to measuring the value of the patent right itself. The downside of using patent renewals to measure value is that because renewal fees are relatively low (typically of the order of a few thousand dollars or euros, at most), this approach conveys relatively little about the valuable tail of the value distribution, where there are few patents but they are worth a great deal. It is also worth pointing out that the renewal method captures the value of the patent right relative to having the patented invention in the public domain.

Other methods for estimating patent value capture different aspects of value of the patent right or the patented invention. These include those based on surveys of individual patentholders and their patents and the use of market valuation of a firm including its patent portfolio. The first approach was pioneered by Sanders et al. (1958) with a survey of U.S. patentholders. Following up on Scherer's analysis of the Sanders et al. data, Harhoff, Scherer, et al. $(1999,2003)$ surveyed a number of German and U. S. holders of German patents, asking them the following question:

"If in 1980 you had known how its contribution to the future profitability of your enterprise would unfold, what is the minimum price for which you would have sold the patent, assuming that you had a goodfaith offer to purchase??"14

This study was followed by a larger study of European inventors that asked essentially the same question of European patentholders (Gambardella et al. 2008). ${ }^{15}$ As these authors point out, the value measured in this instance is the value of owning the patent right relative to a situation where another firm owns the patent, which is not the same value as that revealed by the renewal approach:

"Because the question asks about a hypothetical situation in which the patent is sold, the value measure obtained from the answer logically includes a strategic component of patent value not captured by the renewal value. The reason is that the buyer of the patent will obtain the exclusive right to the patent and may be able to block related patents of the previous owner, thus preventing the original patent holder from practicing these inventions or demand license fees for them. Another way

${ }^{14}$ Harhoff et al. (2003), p. 1348.

15 The PATVAL survey, see Giuri et al. (2007). For the US and Japan, see Nagaoka and Walsh (2009), although in these surveys the value question was much less precise. 
to think about our measure is that it is equivalent to the market value of a firm whose only asset is the patent."16

The authors refer to the value measured in this way as the "asset value." 17 Both of these studies (Harhoff et al. and Gambardella et al.) yielded an extremely skew value distribution, as in the original Sanders et al. data. The mean asset value of a European patent was about 10 times its median, suggesting considerable skewness.

These results are confirmed by those in studies by Scherer (1998) and Silverberg and Verspagen (2007) who find a similar skew value distribution for a number of datasets containing returns to innovation distributions (patent licensing royalties, venture capital investment returns, patent profits according to survey evidence, the number of citations per patent). In general these distributions are either log normal or Pareto with a coefficient whose value ranges from below 1 (no mean to the distribution exists) to around 3 (a mean and a variance exist and the distribution is difficult to distinguish from log normal). In addition, the returns distributions to individual patents or projects are more likely to be Pareto than more aggregate returns distributions.

The authors of the above studies have also shown that patent values are related to a number of bibliometric and other properties of the patent, such as the number of times it is cited, the number of jurisdictions in which a patent on the same invention is taken out, the number of claims, and the number of backward reference made by the patent. For the pioneering work on citations in this area, see Trajtenberg's (1990) study of CT scanners. In this study he finds that patent citations are related not only to private value but to social value. Sampat and A. Ziedonis (2005) show that citations can also help to predict whether a university will successfully license one of its patents, but not the amount of licensing revenue earned.

A second line of work in this area relates the market value of a firm to its patent portfolio and possibly the characteristics of that portfolio, using a methodology introduced by Griliches (1981) that is essentially hedonic. Hall (2000) surveys some early work relating measures of Tobin's q for individual firms to their stock of innovation assets, proxied by R\&D and/or patents. Tobin's q is the ratio of the market value of the firm to the replacement value of its tangible assets, which is assumed to be close to unity in equilibrium (and in the absence of other assets). Discrepancies in the ratio are expected to be correlated with the value of the intangible assets held by the firm, chief among which are its innovation assets.

${ }^{16}$ Gambardella et al. (2008), p. 70.

${ }^{17}$ Scherer (2010) includes a useful discussion on page 25. Asset value is defined as the value of a firm that owns only the patent. 
The first paper to include a citation-weighted measure of patents in this regression was Hall et al. (2005), who found that citations conveyed information about firm value above and beyond that conveyed by R\&D and patenting. In addition, they showed that the relationship was highly nonlinear: Firms that averaged fewer than the average citations per patent across all firms received no boost to market value whereas firms in the top 17 per cent of the sample had a market value that was 35 per cent higher and those in the top 5 per cent, 50 per cent higher, other things equal. It was also noteworthy that self-citations (citations to a firm's own patents) were more valuable than other citations.

Other recent work using patents as a measure of innovation output in the market value equation is that by Blundell et al. (1999) and Toivanen et al. (2002) for the UK, and Bosworth and Rogers (2001) for Australia. In addition, a very few papers have looked at the market response to patent applications, grants, or announcements. In general, one does not expect large short term increases in market returns from a single patent given the relatively large size of the majority of publicly traded firms available for analysis, but when a firm is primarily a technology firm (e.g., biotechnology firms) it is possible to measure the market impact. Two examples of this kind of work are Austin (1993) and Darby et al. (2004).

\section{Using patents to secure financing}

One consequence of patents viewed as property rights to intangible assets is that they may be useful signals to investors that a startup firm has valuable assets even in the absence of a current profit stream. A series of recent papers have examined patents in this role, showing that although not all technology-intensive startups use patents in this way, in general those that do perform somewhat better than the firms that do not.

Sichelman and Graham (2010) report on a large survey of startup and earlystage companies conducted in 2008 and which is more fully described in Graham et al. (2009). The companies surveyed were in the biotechnology, medical instrument, software, internet, and computer hardware sectors and the survey results provide a rich set of information about such companies, in spite of a relative low response rate (approximately 10 per cent, yielding 1000 companies). Unlike non-startup companies, these companies rated financing and improving exit valuation as moderately to very important motives for obtaining patents. In general, biotechnology and medical device firms rated patents much more highly for securing competitive advantage than software and internet firms. This was confirmed by expert investors (venture capital and others), who reported that patents were much more important for their decision to invest in biotechnology than in software and internet firms. Nevertheless, about half of these experts found patents relevant for software and internet.

Mann (2005) reviews the pros and cons of patents for a small sample of software startups, finding that in this technology inventing around is relatively easy, and patents 
can be a distraction from the firm's central activities. However, some firms still amass patents in order to signal quality in later stage financing or for cross licensing purposes. Mann and Sager (2007) find that only one quarter of the venture-backed software firms in their sample acquire a patent, but that firms that do experience better performance in terms of financing, survival, and exit status. Cockburn and MacGarvie (2009) look at how financing and performance vary across software sectors with respect to the presence of patent "thickets" (subareas that are densely populated with patents). They find that both financing and IPOS are delayed in markets that are associated with patent thickets, implying that such thickets may be an impediment to innovative entry.

Looking at technologies other than software, Haeussler et al. (2009) find that European patent applications (but not grants) serve as an important signal to VC investors in German and British biotechnology firms. For nanotechnology, the type of patent matters: an additional patent increases the amount of $\mathrm{VC}$ funding available to a firm, but only if the patent is indeed in the nanotechnology area (Munari and Toschi 2007). Hsu and Ziedonis (2008) look at 370 venture-backed semiconductor firms and report a number of positive effects of patent applications for funding: a doubling in patent application stock is associated with a 28 percent boost in funding-round valuations. This signaling value of patents is greater in earlier financing rounds and when funds are secured from prominent investors. Larger patent application stocks increase both the likelihood of sourcing initial capital from a prominent venture capitalist and of achieving liquidity through an initial public offering.

With the exception of Haeussler et al. (2009), most of the above work on patents and VC financing availability has focused on US firms and used US patents. An exception is Helmers and Rogers (2011), who look at all high and medium technology startups in the UK in a single year, 2000. Using a sample selection model to control for exit, they investigate the impact of having UKIPO or EPO patent applications during 2000 or 2001 on asset growth during the 2001-2005 period, finding a positive effect. This paper is noteworthy for the care with which it discusses the problem that is endemic to all the work in this area: the fact that firms that patent may be different (better) in unobservable ways from firms that do not patent and we may be attributing too much to the patenting decision given inability to control for the quality of their technology. Nevertheless, patents can be interpreted as signals of this quality, so the results are still of some interest. The interpretative problem is similar to the one described earlier: we are not sure whether the patent right is important or simply the underlying invention for which the patent is a proxy. 


\section{Current policy topics}

\section{Software and business method patents}

A series of court decision during the mid to late 1990s in the United States opened the door to a flood of software and business method patents. In consequence, other patent systems, especially those in Europe, have been under considerable pressure to reconsider their apparent prohibition of "disembodied" software patents. The growth of this kind of patenting, the associated growth of high profile litigation of these patents and the controversies these phenomena have engendered have inspired a large research literature that attempts to answer the question of whether this expansion of patentable subject matter was positive or negative for innovation in this area. $^{18}$

Analyzing these kinds of patents requires identifying them, and this has proved somewhat difficult. Computer inventions are often described as combinations of hardware and software to solve a particular problem, especially before the changes in patentable subject matter during the mid-1990s. There is still an incentive to do so if patenting outside the United States is contemplated. In addition, most business method and financial inventions described in patents are in fact implemented by software, so making a distinction among these patents is also difficult. ${ }^{19}$ As Allison (Allison and Tiller 2003; Allison et al. 2011) has argued in several papers, the only way to identify these patents accurately is to read them. But this is impracticable for large statistical studies, so authors such as Graham and Mowery (2002), Bessen and Hunt (2004), and Hall and Macgarvie (2010) have used other methods such as patent classes and keywords. All agree that patenting by software firms was relatively inconsequential during the 1990s, although it began to increase with the dotcom boom just before 2000 .

Bessen and Hunt (2004) were among the first to look at the trends in software patenting following these changes to the law. They show that fewer than 5 per cent of software patents (by their definition, which is rather broad) are held by software firms; most are held by computer hardware and electronics firms. Although the number held by software firms has increased since the period covered by their study (1980-1996), largely owing to increased patenting by large firms such as Adobe, Microsoft and Oracle, it is still true that most software firms hold no patents, even using a broad definition (Bessen 2011).

${ }^{18}$ Using a very broad definition of software patents (US classes 341, 345, 370, 375, 380-382, 700-707, 715-717, 726, and 902) Bessen (2011) finds that annual grants of software patents at the USPTO have increased by a factor of 16 between 1984 and 2009, whereas the number of software patent lawsuit filings has increased by a factor of almost 30 .

\footnotetext{
${ }^{19}$ For research focused specifically on financial and business method patenting, see Hunt (2008) Komulainen and Takalo (2009), Lerner (2001, 2008), Merges (2003), and Wagner (2008).
} 
The rise is software patenting has generated several policy concerns: first, there have been many critiques of their quality in the sense that some are perceived not to satisfy novelty and non-obviousness requirements, probably partly because the USPTO initially did not have computer science experts among its examiners. ${ }^{20}$ Second, this sector is one where innovation is especially cumulative and therefore one where the overall impact of patents may be expected to be negative for innovation, as discussed earlier in this article. Unfortunately such a hypothesis is difficult to test because of the absence of a true counterfactual. Several researchers have looked at related questions: how did the change in the patentability of software affect entry of new firms into the sector, and how did it affect the market valuation of existing firms with and without patents?

In an early look at the entry question, Graham and Mowery (2002) found no effects on entry as of the late 1990s. Cockburn and MacGarvie (2011) asked how software patenting affected entry into various subsectors of the software sector and found that firms were less likely to enter product classes in which there are more software patents, but that, all else equal, firms holding software patents were more likely to enter these markets and that patents were associated with higher survival rates. Hall and MacGarvie (2010) looks at the market response to the important patentability decisions of 1994-1996 and finds that the market evaluated the introduction of software patents as a negative development ex ante. Ex post, a greater number of firms in all ICT sectors invested in these patents, and these firms had slightly higher market values than those with no software patents, with the exception of pure software firms. Overall, the conclusion was that given software patentability, ICT firms engaged in patent portfolio races needed to add software patents to their portfolio, but there was no particular positive impact on software innovation per se.

\section{University patenting}

One policy area that has generated a surprisingly large amount of research recently concerns the role of patenting in the conduct and diffusion of scientific research generated by universities and public research organizations. Although university patenting remains low as a share of all patenting, it has been growing fairly rapidly at least since the Bayh-Dole Act in the United States (1980 with important amendments to the law in 1984) and similar changes elsewhere in the world. Reasons for this are not hard to find: the increased importance of scientific knowledge in the production of certain kinds of innovation, notably those in the biotechnology area, changes in the legal treatment of the ownership of university patents, and budget pressures on the university that have led to it seeking new income sources. A useful

\footnotetext{
${ }^{20}$ See Hall (2009) for a review of these critiques. The rise in requests for re-examination and the low success rates of patent litigation in the software patent area discussed later in the paper also suggest some uncertainty over patent validity.
} 
survey of the broader topic of university-industry relationships that includes a discussion of the role of patents is provided by Foray and Lissoni (2010). Mowery et al. (2004) present a detailed study of the impact of the Bayh-Dole Act on both university research and patenting. ${ }^{21}$

One reason for the enormous interest of academic researchers in this topic may be the demand from their own university administrators for ways to evaluate the consequences of these trends, as there have been many critics who complain that university use of proprietary protections for knowledge detracts from their primary mission as creators of public knowledge. Thus the questions addressed in these papers are whether patenting distracts researchers from research leading to publications, whether patenting changes the nature of their research towards research directed at commercial ends, and whether university patenting slows the diffusion of knowledge by privatizing some of it.

Henderson et al. (1999) was the first paper to examine the changes in university patenting after the Bayh-Dole Act comprehensively. Using all university held U. S. patents applied for between 1965 and 1988, these authors show that such patents are more highly cited and more general, but that the difference in the citation rate falls over time, becoming insignificant after 1984. Sampat et al. (2003) reexamine these data using seven additional years of citations (11-14 years total as compared with 4-7 years), finding that although the gap between university-owned patents and a control sample narrows slightly, university-owned patents have a significantly higher citation rate throughout the period. Both of these papers control for differences across patent classes in average citation rates.

Thursby and Thursby (2007) show theoretically that licensing of applied research results can have a positive impact on the basic research output of universities, for income effect reasons and because of joint production. A number of papers using both U.S. and European data have examined whether patenting by academic research affects their research productivity as measured by publications and all have reached the same conclusion: publishing and patenting are complementary activities, not substitutes, when looking across researchers (Azoulay et al. 2009; Breschi et al. 2007; Carayol 2007; Fabrizio and DiMinim 2008; Thursby and Thursby 2009). There is some evidence that research quality may be affected (Fabrizio and Di Minim) or that research is shifted to areas with more commercial interest (Azoulay et al.). However, Thursby and Thursby (2002) find little change to university research from patent licensing. It is probably safe to summarize this work as showing that patenting and publishing are complements across researchers (more productive researchers do more of both) but

${ }^{21}$ A recent special issue of Research Policy (Grimaldi et al. 2011) is devoted to the topic of academic research 30 years after Bayh-Dole and a recent special issue of Economics of Innovation and New Technology (Geuna and Mowery 2007) to the effects of academic patenting in the US and Europe. 
that they are slight substitutes within researcher (doing more of one inevitably reduces the time available for the other, or at least changes the nature of the research).

Mowery and Ziedonis (2002) look at data on university patenting and licensing for three major research universities before and after the Bayh-Dole Act and find that the impact on research content is very modest with no decline in the importance or generality of their patents, while the impact on the marketing efforts of the university technology transfer office is considerable. Looking at research universities as a whole, they find substantial entry into technology transfer and patent licensing and that the patents of the new entrants are less important (as measured by citations) and general than those of universities with extensive patenting experience before Bayh-Dole.

There is other evidence that the institutional attitude and context seems to have a significant effect on the use of patents. Owen-Smith and Powell (2001) survey faculty inventors in two very different research universities, one an elite private institution with a highly active and successful technology transfer office (TTO) and one that is a large state university. Although they are of similar size and rank, the private institution had ten times as many patents in 1998 and fifteen times the licensing revenue. Faculty attitudes toward disclosure to the TTO differed significantly across the two universities and this in turn influenced their success at patenting inventions.

In an interesting study of university software patents, Rai et al. (2009) also find that the "university effect" is very important in explaining behavior. The most important predictor of software patenting by a university is not their $R \& D$ or employment in the computer science area, but their overall patenting. That is, some universities are active in this area and others are not, but patenting is not especially driven by output in a particular research area.

The heterogeneity of university experience with patent licensing is also emphasized by Geuna and Nesta (2006) who looked at European university activity in this area and found wide variation in the extent to which inventions by university researchers were indeed patented by the university rather than industry or the faculty member himself. As in the US, much of the university patenting was in the areas of biotechnology, pharmaceuticals, and genetics. J. Thursby et al. (2007) finds that one quarter of U.S. patents taken out by faculty researchers are assigned to firms rather than universities and that these patents are less basic and more likely to be in the physical than in the biological sciences. Czarnitzki et al. (2009) find that although those German faculty patents that are owned by corporations have a higher value in terms of forward citations, those assigned to academics or public research organizations are more complex, more basic, and have stronger links to science. The authors suggest that this signals weakness in the commercialization of technologies based on basic science in Germany, although it could simply be the natural outcome of the different goals and activities of the two types of institutions. 
In a novel and influential paper, Murray and Stern (2007) look at the knowledge diffusion effects of patenting research output which is also described in a published paper. They exploit the lag between publishing and the patent grant to look at whether future research (measured as citations to the associated paper) is enhanced or discouraged by the proprietary effect of the grant, finding a modest decline in relative citations after the patent is issued. Williams (2011) uses a similar quasi-experimental approach to the analysis of the impact of Celera Corporation's temporary IP on selected gene sequences, finding that Celera's IP led to reductions in subsequent scientific research and product development outcomes, relative to a counterfactual where the same genes were always in the public domain.

A related issue that has received some attention is that of proprietary research tools and materials, which raise the cost of doing research. Although many jurisdictions have an explicit or implicit "research exemption" for those that use patented information solely for research purposes, not all do, and a highly publicized US court decision called this exemption into question (Madey v. Duke University 2002), holding that the so-called exemption was very narrow and did not generally apply to university research. Nagaoka and Aoki (2007) develop a theoretical analysis of the research exemption and conclude that although such an exemption can be justified in multiperiod R\&D competition, it is not necessarily innovation-enhancing in a two stage pioneer-follower model, because it fails to reward the first inventor. They recommend a broad exemption for research on the subject matter of an invention, together with stronger protection for the pioneer in a product market.

Following on the Madey v. Duke University decision, Walsh, Arora, and Cohen (2003) took an early look at the effects of increases in research tool patenting in the drug discovery area. They found that such patenting had little impact thus far due to the work-arounds adopted by university researchers: taking out licenses, inventing around, using an informal research exemption, and developing publicly available research tools.

\section{Patent litigation 22}

Patent litigation is a relatively rare event in most jurisdictions. However, when it occurs, it tends to involve the most privately valuable patents (Allison et al 2004; Harhoff et al. 2003). If a firm believes that a patent is being infringed, it can sue the infringer for damages and/or injunctive relief. Any firm that is alleged to have infringed, either via a specific letter of notification or by being a defendant in a suit, may sue the patent-holder for declaratory relief, i.e., for a judgment that the firm is not infringing a patent held by the defendant, or that the patent in question is not valid.

\footnotetext{
${ }^{22}$ See Harhoff (2009) for a detailed survey and discussion of patent litigation in various European countries.
} 
Most patents are never litigated; for example, the rate of patent litigation in the U. S. in recent years has been approximately 1 to 2 per cent of patents, with substantial variation across fields (Lanjouw and Schankerman 2001; Bessen and Meurer 2005). Most cases are settled privately and only a few go to trial. The infringement filing rate for EPO-granted patents in Germany has been estimated to be $0.9 \%$ and is thus slightly lower than that in the U.S., even though litigation is considerably less costly in Germany. While patent litigation is relatively rare, cases which are litigated can cause considerable welfare losses, e.g., if the patents have been granted erroneously or if infringement takes place and undermines incentives for R\&D. Important design elements of litigation systems are the financing of the court system, the availability of strategic instruments that can be used unilaterally to affect the cost levels of a rival, and the availability of injunctions.

Because of the need to gather a great deal of information, and because considerable expertise is required, patent litigation systems are usually expensive. Seeking full recovery of court costs from private parties may lead to high litigation costs (as in the United States, Ireland and Great Britain) and, indirectly, to high incidence of private settlements. While that may be optimal in some cases, it is clearly not if adjudication delivers important information about patent validity (Shapiro 2003). In this case, adjudication is the source of positive externalities, and public sector financing of patent litigation would be justified.

Research on patent litigation is difficult because of the data collection problem (it frequently requires accessing the records of courts in several different jurisdictions) but in recent years there have been series of studies of US patent litigation (Moore, 2000; Lanjouw and Schankerman, 2001; Bessen and Meurer, 2005; Henry and Turner, 2006; Allison et al., 2011) and at least one of the German system (Cremers, 2004). ${ }^{23}$ All of these studies document the fact that litigated patents tend to be the more valuable patents, as one might have expected. The US studies also show that only about five per cent of such suits go to trial, with the remainder being settled before going to trial. They also show that whether patent litigation has increased depends on whether it is measured in aggregate or per patent. That is, the increase in patent litigation has roughly paralleled the increase in patenting, at least in the United States, although there is some indication that the litigation rate has risen in the very recent past (Bessen and Meurer, 2005).

One of the consequences of the uncertain quality and breadth of software and business method patents has been increased litigation. Lerner (2008) reports that financial patents are litigated at a rate between 27 and 39 times higher than other patents, and are predominantly being asserted by small entities or individuals against

\footnotetext{
${ }^{23}$ For an early survey of the empirical literature on IP enforcement, see Lanjouw and Lerner (1998).
} 
large firms. Allison et al (2011) examine a new database on patent litigation which is arguably more complete than previous sources and they find that among the patents litigated more than 8 times, three quarters are software patents including business method patents. In principle such patents should be very strong, given the willingness of their owner to litigate, and they are the subject of settlement slightly more frequently than other patents. However, when they do go to trial, the patentholder wins only 13 per cent of the cases, as opposed to 51 per cent of cases involving non-software patents. These results are consistent with the models presented by Farrell and Shapiro (2007) and Reitzig et al. (2007), which emphasize the ability of a holder of even a weak patent to hold up a firm that produces a product that may infringe on the patent for more than the (expected) value of the contribution to the product.

\section{Design of the system}

International treaties have led to some harmonization of patent systems over the past decades, but important differences remain and some of these differences seem to have first-order effects regarding the impact of patent protection on innovation and competition. Researchers have only started to explore this area, and much can still be learned from comparative studies of patent systems. We discuss some of the more recent studies regarding the role of fees and other costs of patenting, the timing of examination, the design of post-grant review, and finally patent office governance and management.

Fees

Patent offices charge fees for a number of steps in the patenting process, such as filing, search, examination, grant, re-examination or opposition, and appeal. Fees are in some cases contingent on the patent application itself, e.g., the number of pages submitted and the number of claims. Many practitioners have argued that fees account for only a small fraction of total patenting costs which are typically dominated by attorney fees. But fees often represent marginal costs while attorney fees are largely sunk ex ante. Recent empirical evidence points to a considerable impact of fees - while the elasticities associated with particular fees tend to be below unity, indicating inelastic reactions, they are not small. Fee changes may therefore be important elements of patent office policies.

De Rassenfosse and von Pottelsberghe (2010) point to the fact that controversies regarding the setting of fees are by no means new, but have received growing attention given that patent systems are again trying to manage a growing back-log of applications and quality problems. The authors distinguish between pre-grant and post-grant costs and fees, where the first group has received the least attention so far, but recent fee changes have created unique opportunities to quantify the impact of these fee types. In December of 2004, the USPTO changed its "excess claims fee": while it had charged \$18 
for any claims exceeding 20 claims up to that date, it increased the claims fee to $\$ 50$ (Archontopoulos et al. 2007). The average number of claims per patent fell from 28 to 23 subsequent to this change. Patents with more claims take longer to examine (Harhoff and Wagner 2009, Lazaridis and van Pottelsberghe 2007), hence the fee change should have led to a reduction of patent office workload. Regarding other pre-grant fees, de Rassenfosse and van Pottelsberghe (2010) summarize evidence from eight studies which all point to inelastic demand with elasticities ranging between -0.03 and -0.60 . Panel data estimates for the trilateral offices (EPO, JPO, USPTO) indicate a long-term elasticity of about -0.30 (de Rassenfosse and van Pottelsberghe 2011).

Of all fee types, most attention has been awarded to post-grant renewal fees. Theoretical and empirical investigations have shown that renewal fees can serve an important purpose by giving incentives to patent-holders to let technologies not valuable to them lapse into the public domain. Moreover, the fee structure (mostly that at European patent offices) has been used to design powerful structural estimation approaches with applicability far beyond the field of patent economics. The early work by Pakes (1986) and Schankerman and Pakes (1986) has been followed by more comprehensive empirical analyses by Lanjouw (1998) and Serrano (2010), encompassing aspects such as litigation and additional options such as the sale of the patent. Cornelli and Schankerman (1999) and Scotchmer (1999) have contributed theoretical studies that demonstrate the optimality of patent renewal systems under certain conditions. As to the impact of renewal fees on the patents in force, Danguy and van Pottelsberghe (2009) estimate from cross-sectional data covering the USA, Japan and 15 European countries that the elasticity of the maintenance rate with respect to the renewal fee rises from -0.03 at year 6 to -0.80 at year 20 .

At the European Patent Office, additional types of fees apply since the EPOgranted patent has to be validated by the applicant at each of the national offices for which patent protection is sought. Using data on validations, validation fees and early renewal fees for EPC countries, Harhoff et al. (2009a) compute an elasticity of -0.30 of validation of between-country validation flows with respect to validation and early renewal fees. Using data at the patent level, Harhoff et al. (2009b) show that increasing validation fees by $1 \%$ reduces validation probabilities by $5.3 \%$. Increasing early renewal fees by $1 \%$ leads to a reduction of validations by $13.7 \%$. Again, the behavior turns out to be inelastic, but fee levels leave noticeable traces in applicant behavior.

Taken together, the studies demonstrate that patent office fees as well as translation requirements are effective determinants of applicant behavior. Hence, they are legitimate tools for patent policies. A comprehensive assessment of an optimal fee structure is still elusive at this point, and it can probably not be conducted without taking other design elements into account. Moreover, political economy issues come into play when fee levels are being discussed. We discuss these below in our comments on patent office governance. 


\section{Timing}

One of the most neglected aspects of patent system design concerns the timing of the pre-grant phase. The concept of "deferred examination" which is of high practical importance in many patent systems has only recently received serious attention among economists (Thomas 2010). Deferred examination was "invented" by Dutch policymakers in the 1960s as a response to mounting backlogs at the Dutch patent office. The innovation spread quickly to other patent offices. Today, most countries allow applicants to file examination requests as late as three years after the application date (Argentina, China, Czech Republic, India, Russia, Slovenia, Taiwan, and Japan since October 2001) or even five years after the application date (Australia, Costa Rica, Korea, Thailand, and Canada since October 1996). At the JPO (prior to October 2001), CIPO (prior to October 1996) and the German Patent Office (DPMA), patent examination has followed or still follows a deferred request system where applicants may ask for examination within seven years after the application date. In all of these countries, publication occurs 18 months from the priority date of the application - hence, deferred examination should not be confused with "submarine patenting" in patent systems that publish applications at the time of grant.

There are a two major exceptions. At the USPTO, patent examination occurs automatically - applicants do not have to file a request. At the EPO and several national patent offices, patent examination needs to be requested within 6 months of the publication of the search report. This is usually 24 months after the priority date (and for most EP filings 18 months after the application date given that applicants at the EPO typically make full use of the priority year). Thus, only the EPO and the USPTO as well as very few other national offices appear to seek an early start of patent examination, while most countries allow applicants to file a request for examination within a given time period following the application date or - in some cases - the publication of the search report. In some countries, failure to do so automatically leads to a lapse of the application which is then "deemed to be withdrawn". Moreover, most countries allow third parties to file an examination request in order to prevent strategic delay of examination. The respective third party then has to pay the examination fee. Furthermore, in some countries, the respective patent office may decide on its own behalf to examine a patent application.

The main effect of deferred examination is a substantial reduction of patent office workload. At the DPMA, only two thirds of all applications handled by the office are ever examined. The remaining applications are dropped by the applicants. About one fifth of all decisions are made in the final year of the deferment period. Long deferments are particularly frequent in pharmaceuticals and chemicals. Applicants at DPMA start paying renewal fees in year 3 (irrespective of the legal status of the application), and these fees are increasing over time. 
The JPO switched to a 3-year deferment option in October 2001. Prior to this reform (which was accompanied by changes in fees and the transition to multiple-claim patents) applicants had a seven-year period to make decisions. Since the JPO system was affected by a number of changes (such as the shift to multiple claims system in January 1988 and major changes in the fee structure in April 2004), the impact of the reduced deferment period is difficult to elicit. Yamauchi and Nagaoka (2009) estimate that the rate of eventual examination requests increased by about 8.6 percentage points due to the change of the deferment period. As expected, the effects were stronger in the technology areas with higher uncertainty where delay is likely to have high option value. In some fields the increase was dramatic - for example, for pharmaceuticals patents from $50.3 \%$ in September 2001 to $76.5 \%$ in October 2001. The authors conclude that the overall impact of the policy change could have been Paretoworsening.

At the Canadian Intellectual Property Office (CIPO), a seven-year deferment, first-to-file system was instituted in 1989, combined with a statutory term of the patent of 20 years from the date of filing. Then in 1996 CIPO went from the seven-year deferment period to a five-year deferment option for applicants. Under the seven-year deferment system, only 67 percent of all applications were ever examined while one third of applications dropped out. After the change and until 2002, 75 percent of applicants requested examination, for an additional examination load of 8 percent (Harhoff 2011).

While the reduction in patent office workload is one major advantage of the deferment system, there is a second one as well: if applicants are not given a regular option of delay, they may "purchase" such an option privately by filing divisional or continuations, or by filing applications that are complex and thus take longer to be examined (Guellec et al. 2007). In a comparison of U.S. and Canadian equivalents, i.e. patents with exactly the same underlying priorities, Harhoff (2011) finds strong evidence supporting this hypothesis. US equivalents corresponding to CIPO patents for which long deferment periods were used were often continuations or continuations-inpart.

Despite of these advantages, deferred patent examination may not be a magic cure for patent offices. It comes at the cost of enhanced uncertainty for rivals of an applicant who keeps an application in play (McGinley 2009). Henkel and Jell (2010) use survey data to show that "creating uncertainty" is an important motive for requesting examination at the DPMA relatively late. It remains to be analyzed to which extent strategic generation of uncertainty can be kept at bay by administrative measures, for example the right for third parties to request examination or by examination initiated by the patent office itself. Nonetheless, the results confirm the view that immediate examination may not be efficient for all patents, and that applicants should be given some flexibility, possibly at a price that dampens incentives for mere generation of 
uncertainty. Taking such considerations into account the USPTO recently announced a plan to let applicants choose from three examination tracks: the examination timing as previously used, a fast-track option for applicants seeking fast examination (similar to the option of accelerated examination at the EPO) and finally a three-year deferment option.

An important technical implication of the different timing regimes concerns the grant rate. Within a given patent system and with the quality of patent applications being held constant, the grant rate is a reasonable reflection of how permissive the patent office is in granting exclusion rights. Some offices with relatively high grant rates (such as the USPTO) have been criticized for not being sufficiently scrupulous in their examination policies. However, comparisons of grant rates can be hazardous since they typically neglect timing issues. The more time a patent system gives its applicants to withdraw their applications upon the arrival of bad news (e.g., regarding technologies, markets or prior art), the lower the grant rate will be. This is not a consequence of particularly exacting procedures in search and examination - it rather reflects applicants' drop-out behavior under deferred examination.

\section{Post-grant review}

Many patent systems (such as those in Australia, Austria, China, Germany, Japan, the US, and at the EPO) offer some form of administrative post-grant review mechanisms that offer third parties an opportunity for challenging a granting decision. These institutions have highly divergent rates of utilization and impact. For example, while the patent opposition mechanism at the EPO and the DPMA is used relatively frequently, mechanisms of patent re-examination at the USPTO have been less successful. We briefly describe the opposition mechanism at the EPO which embodies many of the institutional design aspects also found at other offices.

Any third party can oppose the European patent at the European Patent Office within nine months of a patent's grant by filing an opposition against the granting decision. Opposition can be filed by any third party, but not by the proprietor of the patent, and its outcome is binding for all states in which the patent granted by the EPO has effect. If opposition is not filed within nine months after the grant, the patent's validity can only be challenged under the legal rules of the respective countries in which the patent has been validated. The EPO opposition procedure is the only centralized challenge process for European patents. Opposition may be filed on various grounds. These are (i) the subject matter is not patentable, (ii) the patent does not disclose the invention sufficiently clearly or completely so that it can be carried out by a person skilled in the art, or (iii) the subject matter of the European patent extends beyond the content of the original application. If found valid, an Opposition Division (OD) panel consisting of three technical examiners, two of whom must have taken no part in examining the opposed patent, determines the outcome of the case. 
Opposition proceedings at the EPO may have one of four possible outcomes. First, the patent may be upheld without amendments, i.e., the opposition is rejected. Second, the patent may be fully revoked. Third, when amendments are proposed by the patentee, the patent may be maintained in amended form, a process that often takes the form of a negotiation between the parties, with the OD serving as mediator. Finally, the opposition procedure may be closed, which means either that the opposition has been withdrawn or that the patent has been allowed to lapse. Either of the parties may appeal the outcome once. Opposition at the EPO results in a revocation of the patent in about $30 \%$ of all cases. Amendments and rejections account for another $30 \%$ each, and cases are closed without adjudication in about $10 \%$ of the cases (Graham and Harhoff 2009). By the end of 2009, 6.3\% of EPO-granted patents had been opposed. The opposition rate has been declining from $10.8 \%$ in 1981 to $5.2 \%$ in 2009 .

EPO opposition proceedings have been compared to US re-examination and litigation in a number of studies. See Hall et al. (2003), Graham et al. (2003) and Graham and Harhoff (2009). In the USA, the validity of a patent can be challenged in two forums: within the administrative agency (USPTO) or in the judicial branch (courts). The administrative process most often used, the reexamination, is ex parte (giving the patentee exclusive rights to communication with the decision-maker) and substantially restricts the involvement of the challenger. Graham et al. (2003) document the limited use, and usefulness, of the US reexamination proceeding, showing that only $0.3 \%$ of patents granted between 1991 and 1998 were reexamined, and that patent owners initiated more than half of these reexamination requests. A refinement of the procedure introduced in 1999, the inter partes reexamination, allows challengers more access, but creates such substantial disincentives to challengers that it has far less used in practice (Farrell and Merges, 2004; Shang, 2009). Very recently, use of this form of re-exam has begun to increase, quadrupling between 2006 and 2010, although it is still true that fewer than one per cent of patents are subject to either kind of re-examination. It is noteworthy that about half of the re-examination requests in 2010 are known to be associated with patent litigation (USPTO 2010).

\section{Patent office governance and human resource management}

Patent offices have historically been designed as public administrative entities. In most countries they are part of national ministries without any discretionary authority regarding fee policies and financing. Usually, excess income from fees is maintained in favor of the public treasury, and shortfalls in financing are equally covered by public sources. Most governments seek to have their patent office operations financed by fees, rather than subsidize them permanently or use them as income sources. From a public economics perspective, such a policy appears plausible, yet there is no assurance that fee structures implementing a fully privately financed patent system are optimal in terms of overall welfare. 
Patent office designs and policies have immediate implications for a large number of stakeholders, among them inventors, applicants, patent attorneys, patent examiners and office staff, decision-makers in governing bodies and member states in the case of pan-national patent organizations.

Governance problems may occur for a number of reasons. Most fee structures are "back-loaded", i.e. renewal and other post-grant fees are considerably higher than the marginal costs of the concomitant administrative processes while application, search for prior art and examination are more costly to the patent office than the corresponding fees. While this structure may be justified regarding the impact of fees (i.e. the elasticity of demand), the academic discussion has paid little attention to the within-office incentive problems arising from such structures. High income from granted patents may induce patent offices to grant more patents than is socially optimal.

Similarly, internal accounting rules that grant patent examiners more recognition for the effort leading to a grant rather than a refusal of a patent application may lead to similarly dysfunctional incentives (Friebel et al. 2006). The structural aspects of governance (i.e., a patent office preference for many grants) may translate into management practices which award grants and discourage refusals.

\section{Concluding thoughts}

In this concluding section, we will forego a summary of the preceding sections, as such a summary if adequately done would inevitably be long and repetitive of earlier summaries in the article. Instead we try to highlight a couple of the larger themes and insights we think have been gained.

A first observation is that the sheer size and growth of the recent literature might lead one to assume that patents are an extremely important instrument of economic development and growth, which therefore attract a great deal of interest from researchers and policy makers. But this seems at odds with the weak evidence that patents serve as an incentive for innovation and the fact that relatively few firms find them an important means of securing returns to innovation. We think that the answer to this conundrum has several pieces: First, a small subsector of industry, mostly pharmaceuticals, does find them very useful and even essential as an incentive. Second, although they are not important for innovation incentives in general, if your competitors have them, you need them too, which effectively means they are a zero sum game for the economy as a whole but necessary for each individual firm (Gambardella and Hall 2006). Third, although patents may not add much to social welfare (and are therefore not visibly effective in aggregate studies), they are capable of generating large private returns in many instances, which means that a number of economic actors have an interest in them, creating demands for more research. 
With respect to the overall effectiveness of patents in encouraging innovation, another thing we have learned from this research is that seemingly minor changes in the institutional design of patent systems can have relatively large effects. The question of whether patents do or do not have positive welfare implications cannot be answered without stating which form of a patent system is being compared to the counterfactual patent-free world. Our reading of the literature is that researchers are still far away from fully understanding the impact of the institutional aspects of patent systems. That should give both abolitionists as well as advocates of an ever-enlarging patent system reason to pause. Despite all of their weaknesses, international comparisons of patent systems look like a promising avenue for gaining more insights. However, the main impediment to improving patent systems many not lie in gaining new insights, but in the political economy of patent systems and the vested, often diverging interests that many stakeholders have in the existing system.

\section{Literature cited}

Allison JR, Lemley MA, Moore KA, Trunkey RD. 2004. Valuable patents. Georgetown Law Journal 92: 435-79

Allison JR, Lemley MA, Walker J. 2011. Patent Quality and Settlement among Repeat Patent Litigants. Georgetown Law Journal 99: 677-712

Allison JR, Tiller EH. 2003. Statistical Analysis of Internet Business Method Patents. In Intellectual Property in the Knowledge-Based Economy, ed. WM Cohen. Washington, DC: National Academies Press

Anton JJ, Yao DA. 2004. Little Patents and Big Secrets: Managing Intellectual Property. Rand Journal of Economics 35(1): 1-22

Archontopoulos E, Guellec D, Stevnsborg N, van Zeebroeck N, van Pottelsberghe de la Potterie B. 2007. When small is beautiful: Measuring the evolution and consequences of the voluminosity of patent applications at the EPO. Information Economics and Policy 19(2): 103-132

Arora A, Ceccagnoli M, Cohen WM. 2003. R\&D and the patent premium. Cambridge, MA: NBER Working Paper No. 9431

Arora A, Fosfuri A, Gambardella A. 2001. Markets for Technology: The Economics of Innovation and Corporate Strategy. Cambridge, MA: MIT Press

Arora A, Merges RP. 2004. Specialized Supply Firms, Property Rights, and Firm Boundaries. Industrial and Corporate Change 13: 451-475

Arundel A. 2003. Patents in the Knowledge-Based Economy: Report of the Know Survey. Maastricht: MERIT, University of Maastricht 
Austin DH. 1993. An Event-Study Approach to Measuring Innovative Output: The Case of Biotechnology. American Economic Review 83: 253-58

Azoulay P, Ding W, Stuart T. 2009. The Impact of Academic Patenting on the Rate, Quality and Direction of (Public) Research Output. Journal of Industrial Economics 57: 637-76

Baldwin JR, Hanel P, Sabourin D. 2000. Determinants of innovative activity in Canadian manufacturing firms: the role of intellectual property rights. Working Paper No. 122. Ottawa: Statistics Canada

Baudry M, Dumont B. 2009. A Bayesian real option approach to patents and optimal renewal fees. Nantes, France: LEMNA Working Paper 2009/09

Belenzon S. 2006. Knowledge flow and sequential innovation: Implications for technology diffusion, R\&D and market value. Oxford, UK: Nuffield College, Oxford University, available at http://www.economics.ox.ac.uk/Research/wp/pdf/paper259.pdf

Bessen, J. 2011. A generation of software patents. Boston University School of Law Working Paper No. 11-31. Available at http://www.bu.edu/law/faculty/scholarship/workingpapers/2011.html

Bessen JE, Hunt RM. 2004. An Empirical Look at Software Patents. Philadelphia, PA: Federal Reserve Bank of Philadelphia Working Paper No. 03/17R

Bessen J, Maskin E. 2009. Sequential innovation, patents, and imitation. Rand Journal of Economics 40: 611-635

Bessen J, Meurer MJ. 2009. Patent Failure: How Judges, Bureaucrats, and Lawyers Put Innovators at Risk. Princeton, NJ: Princeton University Press

Bessen J, Meurer MJ. 2005. The patent litigation explosion. Law and Economics Working Paper No. 05-18, Boston University School of Law

Bhattacharya S, Guriev S. 2006. Patents vs. trade secrets: Knowledge licensing and spillover. Journal of the European Economic Association 4(6): 1112-1147

Bloom N, Van Reenen J, Schankerman M. 2007. Identifying technology spillovers and product market rivalry. CEPR Discussion Paper No. 4912. London, UK: CEPR

Blundell R, Griffith R, Van Reenen J. 1999. Market Share, Market Value and Innovation in a Panel of British Manufacturing Firms. Review of Economic Studies 66: 529-54

Boldrin M, Levine DK. 2008. Against Intellectual Monopoly. Cambridge, UK and New York: Cambridge University Press 
Bosworth D, Rogers M. 2001. Market Value, R\&D and Intellectual Property: An Empirical Analysis of Large Australian Firms. The Economic Record 77: 323-37

Branstetter LG. 2004. Do Stronger Patents Induce More Local Innovation? Journal of International Economic Law 7(2): 359-70

Breschi S, Lissoni F, Montobbio F. 2007. The Scientific Productivity of Academic Inventors: New Evidence from Italian Data. Economics of Innovation and New Technology 16: 101-18

Carayol N. 2004. Academic Incentives and Research Organization for Patenting at a Large French University. Economics of Innovation and New Technology 16: 119-38

Cockburn IM, Macgarvie M. 2011. Entry and Patenting in the Software Industry. Management Science. In press

Cockburn IM, MacGarvie M. 2007. Patents, Thickets, and the Financing of EarlyStage Firms: Evidence from the Software Industry. Journal of Economics and Management Strategy 18: 729-73

Cohen WM, Goto A, Nagata A, Nelson RR, Walsh JP. 2002. R\&D spillovers, patents and the incentives to innovate in Japan and the United States. Research Policy 31: 134967

Cornelli F, Schankerman M. 1999. Patent renewals and R\&D incentives. RAND Journal of Economics 30(2): 197-213

Corrado C, Hulten CR, Sichel DE. 2006. Intangible Capital and Economic Growth. Cambridge, MA: NBER Working Paper No. w11948

Cremers K. 2004. Determinants of patent litigation in Germany. Mannheim, Germany: Centre for European Economic Research (ZEW) Discussion Paper No. 04-72

Czarnitzki D, Hussinger K, Schneider C. 2009. The Nexus between Science and Industry: Evidence from Faculty Inventions. Mannheim, Germany: ZEW Discussion Paper No. 09-028

Dam KW. 1994. The economic underpinnings of patent law. The Journal of Legal Studies 23: 247-271

Danguy J, van Pottelsberghe de la Potterie B. 2009. Cost-benefit analysis of the Community Patent. Brussels, Belgium: Bruegel Working Paper 2009/08

Darby MR, Liu Q, Zucker LG. 2004. High Stakes in High Technology: High-Tech Market Values as Options. Economic Inquiry 42: 351-69 
Davis L. 2006. How do Small High-Tech Firms Manage the Patenting Process? DRUID Summer Conference on Knowledge, Innovation, and Competitiveness, Working Paper No. 164. Available at

http://www2.druid.dk/conferences/viewpaper.php?id=164\&cf=8

Deng Z, Lev B, Narin F. 1999. Science and Technology as Predictors of Stock Performance. Financial Analysts Journal 55(3): 20-32

Denicolò V. 2007. Do patents over-compensate innovators? Economic Policy 22(52): 679-729

Denicolò V, Franzoni LA. 2004. Patents, Secrets, and the First-Inventor Defense. Journal of Economics \& Management Strategy 13(3): 517-538

Denicolò V, Franzoni LA. 2003. The contract theory of patents. International Review of Law and Economics 23: 365-380

Denicolò V, Halmenschlager C. 2010. Optimal Patentability Requirements with Fragmented Property Rights. Milano, Italy: Fondazione ENI Enrico Maffei Working Paper No. 134

de Rassenfosse G, Van Pottelsberghe de la Potterie B. 2011. On the Price Elasticity of Demand for Patents. Oxford Bulletin of Economics and Statistics. In press. doi: 10.1111/j.1468-0084.2011.00638.x

de Rassenfosse G, van Pottelsberghe de la Potterie B. 2010. The Role of Fees in Patent Systems: Theory and Evidence. Centre for Economic Policy Research, London: CEPR Discussion Paper No. 7879

de Rassenfosse G, van Pottelsberghe de la Potterie B. 2007. Per un pugno di dollari: a first look at the price elasticity of patents. Oxford Review of Economic Policy 23: 588-604

Encaoua D, Lefouilli Y. 2005. Choosing Intellectual Protection: Imitation, Patent Strength and Licensing. Annales d'Économie et de Statistique 79/80, Special issue of Contributions in Memory of Zvi Griliches, Mairesse J, Trajtenberg M (eds.), 241-271

EPO (European Patent Office). 2007a. Patent system. Available at http://www.epo.org/topics/patent-system.html

EPO (European Patent Office). 2007b. Legislative Initiatives. Available at http://www.epo.org/patents/law/legislative-initiatives.html

Fabrizio KR, Di Minim A. 2008. Commercializing the laboratory: Faculty patenting and the open science environment. Research Policy 37: 914-31 
Farrell J, Merges RP. 2004. Incentives to Challenge and to Defend Patents: Why Litigation Won't Reliably Fix Patent Office Errors and Why Administrative Patent Review Might Help. Berkeley Technology Law Journal 19 (3): 943-970

Farrell J, Shapiro, C. 2008. How Strong Are Weak Patents? American Economic Review 98(4): 1347-1369

Fink C, Khan M, Zhou H. 2011. The Worldwide Surge in Patent Applications. WIPO: Paper presented at the Third Annual Patent Analysis Workshop at ITPS, Seville, Spain, June 13-14. Available at http://is.jrc.ec.europa.eu/pages/ISG/patents/documents/MosahidKhan.pdf

Foray D, Lissoni F. 2010. University research and public-private interaction. In Hall BH, Rosenberg N (eds.), Handbook of the Economics of Innovation, Volume I. Amsterdam: Elsevier, pp. 276-314

Friebel G, Koch AK, Prady D, Seabright P. 2006. Objectives and Incentives at the European Patent Office. Study Commissioned by the Staff Union of the European Patent Office (SUEPO). Available at http://idei.fr/doc/by/seabright/report epo.pdf

Fromer JC. 2009. Patent Disclosure. Iowa Law Review 94: 539-596

Galasso A, Schankerman M. 2010. Patent thickets, courts, and the market for innovation. Rand Journal of Economics 41(3): 472-503

Gallini NT, Scotchmer, S. 2002. Intellectual Property: When Is It the Best Incentive System? Innovation Policy and the Economy 2: 51-77

Gambardella A, Hall BH. 2006. Proprietary vs. Public Domain Licensing of Software and Research Products. Research Policy 35 (6): 875-892.

Gambardella A, Harhoff D, Nagaoka S. 2011. The Social Value of Patent Disclosure. Unpublished manuscript, LMU Munich

Gambardella A, Harhoff D, Verspagen B. 2008. The Value of European Patents. European Management Review 5: 69-84

Gans J, King S, Lampe R. 2004. Patent renewal fees and self-funding patent offices. Topics in Theoretical Economics 4(1): article 6

Geuna A, Mowery DC. 2007. Publishing and patenting in US and European universities. Special issue of Economics of Innovation and New Technology 16(2): 67-70

Geuna A, Nesta LJJ. 2006. University patenting and its effects on academic research: The emerging European evidence. Research Policy 35(6): 790-807 
Ginarte JC, Park WG. 1997. Determinants of patent rights: a cross-national study. Research Policy 26(3): 283-301

Giuri P, Mariani M, Brusoni S, Crespi G, Francoz D, et al. 2007. Inventors and invention processes in Europe: Results from the PatVal-EU survey. Research Policy 36: 1107-27

Graham SJH, Hall BH, Harhoff D, Mowery, DC. 2003. Post-issue Patent 'Quality Control': A Comparative Study of U.S. Patent Re-examinations and European Patent Oppositions. In The Patent System in the Knowledge-Based Economy, ed. WM Cohen, SA Merrill. Washington, DC: National Academies Press, 74-119

Graham SJH, Harhoff D. 2009. Separating Patent Wheat from Chaff: Would the U.S. Benefit from Adopting a Patent Post-Grant Review? SSRN Discussion Paper, available at http://ssrn.com/abstract=1489579

Graham SJH, Merges RP, Samuelson P, Sichelman T. 2009. High Technology Entrepreneurs and the Patent System: Results of the 2008 Berkeley Patent Survey. Berkeley Technology Law Journal 24: 1255-1328

Graham SJH, Mowery DC. 2002. Intellectual Property Protection in the U.S. Software Industry. In The Patent System in the Knowledge-Based Economy, ed. WM Cohen, SA Merrill. Washington, DC: National Academies Press

Green J, Scotchmer S. 1995. On the Division of Profit in Sequential Innovation. Rand Journal of Economics 26, 20-33

Griliches Z. 1990. Patent Statistics as Economic Indicators: A Survey. Journal of Economic Literature 28: 1661-707

Grimaldi R, Kenney M, Siegel DS, Wright M. 2011. 30 Years After Bayh-Dole: Reassessing Academic Entrepreneurship. Special issue of Research Policy 40(8): 10451144

Guellec D, van Pottelsberghe de la Potterie B. 2007. The economics of the European patent system. Oxford, UK: Oxford University Press

Haeussler C, Harhoff D, Mueller E. 2009. To be financed or not...- the role of patents for venture capital financing. Mannheim, Germany: ZEW Discussion Paper No. 09-003

Hall BH. 2009. Business and Financial Method Patents, Innovation, and Policy. Scottish Journal of Political Economy 56: 443-73

Hall BH. 2007. Patents and Patent Policy. Oxford Review of Economic Policy 23: 120 
Hall BH. 2000. Innovation and Market Value. In Barrell R, Mason G, O’Mahoney M (eds.), Productivity, Innovation and Economic Performance. Cambridge: Cambridge University Press

Hall BH. 1993. The value of intangible corporate assets: an empirical study of the components of Tobin's Q. Berkeley, CA: University of California at Berkeley Dept. of Economics Working Paper No. 93-207. Available at http://www.escholarship.org/uc/item/44x548gq

Hall BH, Graham SJH, Harhoff D, Mowery DC. 2003. Prospects for improving U.S. patent quality via postgrant opposition. Innovation Policy and the Economy 4: 115-43

Hall BH, Harhoff D. 2004. Post Grant Review Systems at the U.S. Patent Office Design Parameters and Expected Impact. Berkeley Law Technology Journal 19 (3): 9891016

Hall BH, Helmers C. 2010. The role of patent protection in (clean/green) technology transfer. Santa Clara High Technology Law Journal 26 (2010): 487-532

Hall BH, Jaffe AB, Trajtenberg M. 2005. Market value and patent citations. Rand Journal of Economics 36: 16-38

Hall BH, MacGarvie M. 2010. The private value of software patents. Research Policy 39: 994-1009

Hall BH, Ziedonis RH. 2001. The patent paradox revisited: an empirical study of patenting in the U.S. semiconductor industry, 1979-1995. Rand Journal of Economics 32: 101-28

Hall RE. 2001. The Stock Market and Capital Accumulation. American Economic Review 91: 1185-1202

Harhoff D. 2011. Deferred Patent Examination. München, Germany: LudwigMaximilians-Universität München, manuscript

Harhoff D. 2009. Economic Cost-Benefit Analysis of a Unified and Integrated European Patent Litigation System. Final Report to the European Commission. Available at

http://ec.europa.eu/internal market/indprop/docs/patent/studies/litigation system e $\underline{\text { n.pdf }}$

Harhoff D, Hoisl K, Reichl B, van Pottelsberghe de la Potterie B. 2009a. Patent validation at the country level - The role of fees and translation costs. Research Policy 38(9): 1423-1437 
Harhoff D, Hoisl K, van Pottelsberghe de la Potterie B. 2009b. Languages, Fees and the Regional Scope of Patenting in Europe. Centre for Economic Policy Research, London: CEPR Discussion Paper No. 7241

Harhoff D, Narin F, Scherer FM, Vopel K. 1999. Citation frequency and the value of patented inventions. Review of Economics and Statistics 81: 511-515

Harhoff D, Reitzig M. 2004. Determinants of opposition against EPO patent grants: The case of biotechnology and pharmaceuticals. International Journal of Industrial Organization 22: 443-480

Harhoff D, Scherer FM, Vopel K. 2003. Citations, Family Size, Opposition, and the Value of Patent Rights. Research Policy 32: 1343-1364

Harhoff D, Wagner S. 2009. The Duration of Patent Examination at the European Patent Office. Management Science 55(12): 1969-1984

Haskel J, Giorgio Marrano M. 2007. How Much Does the UK Invest in Intangible Assets? London, UK: CEPR Working Paper No. 6287

Hegde D, Sampat B. 2009. Examiner citations, applicant citations, and the private value of patents. Economics Letters 105: 287-89

Heller MA, Eisenberg RS. 1998. Can patents deter innovation? The anticommons in biomedical research. Science 280: 698-701

Helmers C, Rogers M. 2011. Does Patenting Help High-Tech Start-Ups? Research Policy 40:1016-1027

Henderson R, Jaffe AB, Trajtenberg M. 1998. Universities as a Source of Commercial Technology: A Detailed Analysis of University Patenting 1965-1988. Review of Economics and Statistics 80: 119-27

Henkel J, Jell F. 2010. Patent Pending - Why Faster Isn't Always Better. SSRN Discussion Paper, available at http://ssrn.com/abstract $=1738912$

Henry M, Turner JL. 2006. The Court of Appeals for the Federal Circuit's Impact on Patent Litigation. Journal of Legal Studies 35: 85-117

Hopenhayn H, Llobet G, Mitchell M. 2006. Rewarding Sequential Innovators: Prizes, Patents, and Buyouts. Journal of Political Economy 114(6): 1041-1068

Hunt RM. 2008. Business Method Patents and U.S. Financial Services. Contemporary Economic Policy 28: 322-52

Hunt RM. 2006. When do more patents reduce R\&D? American Economic Review 96(2): 87-91 
Hunt RM. 2004. Patentability, Industry Structure, and Innovation. Journal of Industrial Economics 52(3): 401-425

Hsu DH, Ziedonis RH. 2008. Patents as Quality Signals for Entrepreneurial Ventures. 2008 Academy of Management Best Paper Proceedings. Available at http://www.management.wharton.upenn.edu/hsu/inc/doc/papers/david-hsusignals.pdf

ICTSD and UNCTAD. 2003. Intellectual Property Rights, Implications for Development Policy. Geneva, Switzerland: ICTSD and UNCTAD

James TC. 2007. Patent Protection in India: Policy Trends. Presentation to the Conference on Intellectual Property Rights, Globalisation and Related Issues. Delhi, India: Delhi School of Economics

JPO (Japanese Patent Office). 2006. A history of system of industrial property rights. Online. Available at http://www.deux.jpo.go.jp/cgi/search.cgi?query=history\&lang=en\&root=short, accessed 19 December 2006

Jaffe AB, Lerner J, 2004. Innovation and Its Discontents: How Our Broken Patent System is Endangering Innovation and Progress, and What to Do About It. Princeton University Press, Princeton, NJ

Johnson DKN, Popp D. 2001. Forced Out of the Closet: The Impact of the American Inventors Protection Act on the Timing of Patent Disclosure. RAND Journal of Economics 34 (1): 96-112

Judd KL. 1985. On the performance of patents. Econometrica 53: 567-95

Kanwar S, Evenson R. 2003. Does Intellectual Property Protection Spur Technical Change? Oxford Economic Papers 55: 235-264

Kitch EW. 1977. The nature and function of the patent system. Journal of Law and Economics 20: 265-290

Klemperer P. 1990. How broad should the scope of patent protection be? Rand Journal of Economics 21, 113-30

Komulainen M, Takalo T. 2008. Does State Street lead to Europe? A study of financial exchange innovations. Bank of Finland Research Discussion Paper No. 22/2009, Helsinki, Finland

Ladas and Parry LLP. 2003. A brief history of the patent law of the United States. Online. Available at http://www.ladas.com/Patents/USPatentHistory.html 
Lanjouw J. 1998. Patent Value in the Shadow of Infringement: Simulation Estimations of Patent Value. Review of Economic Studies 65: 671-710

Lanjouw JO, Lerner J. 1998. The Enforcement of Intellectual Property Rights: A Survey of the Empirical Literature. Annales d'Economie et de Statistique 49-50: 223-246

Lanjouw JO, Schankerman M. 2001. Characteristics of Patent litigation: a window on competition. Rand Journal of Economics 32: 129-51

Lazaridis G, van Pottelsberghe de la Potterie B. 2007. The rigour of the EPO patentability criteria: An insight into the "induced withdrawals." World Patent Information 29(4): 317-326

Lee WF, Cogswell LP. 2004. Understanding and addressing the unfair dilemma created by the doctrine of willful patent infringement. Houston Law Review 41: 393-457

Lemley MA, Shapiro C. 2007. Patent holdup and royalty stacking. Texas Law Review 85: 1991-2049

Lerner J. 2008. The Litigation of Financial Innovations, Cambridge, MA: NBER Working Paper No. w14324

Lerner J. 2002. Patent policy shifts and innovation over 150 years. American Economic Review 92: 221-5

Lerner J. 2001. Where Does State Street Lead? A First Look at Finance Patents, 1971-2000. Journal of Finance 57: 901-30

Lerner J. 1995. Patenting in the shadow of competitors. Journal of Law and Economics 38: 463-95

Lerner J, Tirole J. 2004. Efficient Patent Pools. American Economic Review 94(3): 691-711

Lerner J, Zhu F. 2005. What is the Impact of Software Patent Shifts? Evidence from Lotus v. Borland. International Journal of Industrial Organization 25: 511-29

Levin RC, Klevorick AK, Nelson RR, Winter SG. 1987. Appropriating the returns from industrial research and development. Brookings Papers on Economic Activity 1987(3): 783-831

Machlup F, Penrose ET. 1950. The patent controversy in the nineteenth century. The Journal of Economic History 10: 1-29

Madey v. Duke University. United States Court of Appeals for the Federal Circuit, 2002. 307 F.3d 1351; 64 U.S.P.Q.2d (BNA) 1737 
Mann RJ. 2005. Do Patents Facilitate Financing in the Software Industry? Texas Law Review 83: 961-1030

Mann RJ, Sager TW. 2007. Patents, Venture Capital, and Software Startups. Research Policy 36: 193-208

Mansfield E. 1986. Patents and Innovation: An Empirical Study. Management Science 32(2): 173-181

Marco A, Prieger JE. 2009. Congestion Pricing for Patent Applications. SSRN Discussion Paper, available at http://ssrn.com/abstract $=1443470$

Maskus KE. 2004. Encouraging International Technology Transfer. Geneva, Switzerland: ICTSD and UNCTAD Issue Paper No. 7

Maurer SM, Scotchmer S. 2006. Profit Neutrality in Licensing: The Boundary between Antitrust Law and Patent Law. American Law and Economics Review 8: 476522

Mazzoleni R, Nelson RR. 1998. The benefits and costs of strong patent protection. a contribution to the current debate. Research Policy 27: 273-284

McGinley C. 2008. Taking the heat out of the global patent system. Intellectual Asset Management 31: 24-29

Menell PS. 2000. Intellectual property: General theories. Encyclopedia of Law and Economics 2: 129-186

Merrill SA, Levin RC, Myers MB. 2004. A patent system for the 21st century. Washington, DC: National Academy Press

Moore KA. 2004. Empirical statistics on willful patent infringement. Federal Circuit Bar Journal 14: 227-237

Moore KA. 2000. Judges, Juries, and patent cases - an empirical peek inside the black box. Michigan Law Review 99(281): 365-409

Moser P. 2011. Innovation Without Patents - Evidence from the Word Fairs. Available at http://papers.ssrn.com/sol3/Papers.cfm?abstract id=930241

Moser P. 2005. How do patent laws influence innovation? Evidence from nineteenth-century world fairs. American Economic Review 95: 1214-36

Mowery DC, Nelson RR, Sampat BN, Ziedonis AA. 2004. Ivory Tower and Industrial Innovation: University-Industry Technology Transfer Before and After the BayhDole Act. Stanford University Press, Stanford, CA 
Mowery DC, Ziedonis AA. 2002. Academic Patent Quality and Quantity before and after the Bayh-Dole Act in the United States. Research Policy 31: 399-418

Munari F, Toschi L. 2007. How good are VCs at valuing technology? An analysis of patenting and VC investments in nanotechnology. Riunione Scientifica Annuale Aiig: 1-23

Murmann JP. 2003. Knowledge and Competitive Advantage - The Coevolution of Firms, Technologies and National Institutions. Cambridge, UK: Cambridge University Press

Murray F, Stern S. 2007. Do formal intellectual property rights hinder the free flow of scientific knowledge? An empirical test of the anti-commons hypothesis" Journal of Economic Behavior \& Organization 63(4): 648-687

Nagaoka S, Aoki R. 2007. Economic Analysis of Patent Law Exemption for Research on a Patented Innovation. Tokyo, Japan: IIR Working Paper, Hitotsubashi University

Nagaoka S, Walsh JP. 2009. Commercialization and other uses of patents in Japan and the US: Major findings from the RIETI-Georgia Tech inventor survey. Tokyo, Japan: RIETI Discussion Paper

O'Donoghue T. 1998. A Patentability Requirement for Sequential Innovation. Rand Journal of Economics 29(4): 654-679

O'Donoghue T, Scotchmer S, Thisse J-F. 1998. Patent Breadth, Patent Life, and the Pace of Technological Progress. Journal of Economics \& Management Strategy 7(1): 1-32

Owen-Smith J, Powell WW. 2001. To Patent or Not: Faculty Decisions and Institutional Success at Technology Transfer. Journal of Technology Transfer 26: 99-114

Pakes A. 1986. Patents as Options: Some Estimates of the Value of Holding European Patent Stocks. Econometrica 54: 755-784

Pakes A, Schankerman M. 1984. The rate of obsolescence of patents, research gestation lags, and the private rate of return to research resources. In $R \& D$, Patents, and Productivity, Griliches Z (ed), pp. 73-88. Chicago, IL: Chicago University Press

Park WG, Ginarte, JC. 1997. Intellectual Property Rights and Economic Growth. Contemporary Economic Policy XV, 51-61

Penrose ET. 1951. The Economics of the International Patent System. Johns Hopkins Press

Powers MD, Carlson SC. 2001. The evolution and impact of the doctrine of willful patent infringement. Syracuse Law Review 51: 53 
Prager FD. 1946. Brunelleschi's Patent. Journal of the Patent Office Society 28(2): 109-135

Qian Y. 2007. Do Additional National Patent Laws Stimulate Domestic Innovation in a Global Patenting Environment? Review of Economics and Statistics 89: 436-453

Rai A, Allison JR, Sampat BN. 2009. University Software Ownership and Litigation: A first examination. North Carolina Law Review 87: 1519-70

Reinganum JF. 1989. The Timing of innovation: research, development, and diffusion. In Handbook of Industrial Organization, vol. 1, ed. R. Schmalensee and R. D. Willig. Amsterdam: North-Holland

Reitzig M, Henkel J, Heath C. 2007. On sharks, trolls and their patent prey: Unrealistic damage awards and firms' strategies of "being infringed". Research Policy 36(1): 134-154

Rockett K. 2010. Property rights and invention. In Hall, B. H., and N. Rosenberg, Handbook of the Economics of Innovation, Volume I, Chapter 7. Amsterdam and New York: Elsevier

Roin B. 2007. The Disclosure Function of the Patent System: or Lack Thereof. Harvard Law Review 118: 2007-2028

Sakakibara M, Branstetter L. 2001. Do stronger patents induce more innovation? Evidence from the 1988 Japanese patent law reforms. Rand Journal of Economics 32, 77100

Sampat BN, Mowery DC, Ziedonis AA. 2003. Changes in University Patent Quality after the Bayh-Dole Act: A Re-examination. International Journal of Industrial Organization 21: 1371-1390

Sampat B, Ziedonis A. 2005. Patent Citations and the Economic Value of Patents. In Handbook of Quantitative Science and Technology Research, pp. 277-298

Sanders BS, Rossman J, Harris LJ. 1958. The Economic Impact of Patents. Patent, Trademark, and Copyright Journal of Research 2: 340-362

Schankerman M, Pakes A. 1986. Estimates of the Value of Patent Rights in European Countries During the Post-1950 Period. Economic Journal 96: 1052-76

Schankerman M, Scotchmer S. 2001. Damages and Injunctions in the Protection of Proprietary Research Tools. Rand Journal of Economics 32(1): 199-220

Scherer FM. 2010. A Half Century of Research on Patent Economics. WIPO Journal 2 (1): 20-27 
Scherer FM. 2002. The economics of human gene patents. Academic Medicine 77: 1348-1367

Scherer FM. 1998. The size distribution of profits from innovation. Annales d'Economie et de Statistique 49/50: 495-516

Scherer FM. 1967. Research and development resource allocation under rivalry. Quarterly Journal of Economics 81: 359-394

Scotchmer S. 2005. Innovation and Incentives. Cambridge, MA: MIT Press

Scotchmer S. 1999. On the optimality of the patent renewal system. RAND Journal of Economics 30(2): 181-196

Scotchmer S. 1991. Standing on the shoulders of giants. Journal of Economic Perspectives 5(1), 29-41

Scotchmer S, Green J. 1990. Novelty and disclosure in patent law. Rand Journal of Economics 21: 131-146

Serrano CJ. 2010. The dynamics of the transfer and renewal of patents. RAND Journal of Economics 41(4): 686-708

Seymore SB. 2010. The Teaching Function of Patents. Notre Dame Law Review 85 (2): 621-669

Shang R. 2009. Inter Partes Reexamination and Improving Patent Quality. Northwestern Journal of Technology and Intellectual Property 7: 185-209

Shapiro C. 2010. Injunctions, Hold-Up, and Patent Royalties. American Law and Economics Review 12(2): 280-318

Shapiro C. 2007. Prior User Rights. American Economic Review 96(2): 92-96

Shapiro C. 2003. Antitrust limits to patent settlements. RAND Journal of Economics 34: 391-411

Shapiro C. 2001. Navigating the Patent Thicket: Cross Licenses, Patent Pools, and Standard-Setting. Innovation Policy and the Economy 1: 119-150

Sichelman T, Graham SJH. 2010. Patenting by Entrepreneurs: An Empirical Study. Mich. Telecomm. Tech. L. Rev. 17: 111-180

Silverberg G, Verspagen B. 2007. The size distribution of innovations revisited: An application of extreme value statistics to citation and value measures of patent significance. Journal of Econometrics 139: 318-39 
Sterne RG, Garrett PE, Wood TA. 2004. The written description requirement. Akron Law Review 37: 231-241

Thomas JR. 2010. Deferred Examination of Patent Applications: Implications for Innovation Policy. Washington, DC: Congressional Research Service Report 7-5700

Thompson NC, Mowery DC, Ziedonis AA. 2011. Materials Transfer Agreements (MTAs), Licenses, and the Flow of Scientific Knowledge. UC Berkeley and University of Oregon, manuscript

Thursby JG, Fuller A, Thursby MC. 2007. US Faculty Patenting: Inside and Outside the University. Cambridge, MA: NBER Working Paper No. w13256

Thursby JG, Thursby MC. 2009. University Licensing: Harnessing or Tarnishing Faculty Research. Innovation Policy and the Economy 10: 159-189

Thursby JG, Thursby MC. 2002. Who Is Selling the Ivory Tower? Sources of Growth in University Licensing. Special Issue on University Entrepreneurship and Technology Transfer, Management Science 48 (1): 90-104

Thursby MC, Thursby JG. 2007. Are There Real Effects of Licensing on Academic Research? A life cycle view. Journal of Economic Behavior and Organization 63(4):

Toffel MW. 2004. Strategic management of product recovery. California Management Review 46: 120-141

Toivanen O, Stoneman PL, Bosworth D. 2002. Innovation and the Market Value of UK Firms, 1989 - 1995. Oxford Bulletin of Economics and Statistics 64: 39-62

Trajtenberg M. 1990. A Penny for Your Quotes: Patent Citation and the Value of Innovations. Rand Journal of Economics 21: 172-87

USPTO (United States Patent and Trademark Office). 2010. United States Patent and Trademark Office Performance and Accountability Report Fiscal Year 2010. Available at http://www.uspto.gov/about/stratplan/ar/index.jsp

USPTO (United States Patent and Trademark Office). 2011. Patents. http://www.uspto.gov/main/patents.htm

Wagner S. 2008. Business Method Patents in Europe and their Strategic Use Evidence from Franking Device Manufacturers. Economics of Innovation and New Technology 17: 173-94

Walsh JP, Arora A, Cohen WM. 2003. Effects of Research Tool Patenting and Licensing on Biomedical Innovation. In The Patent System in the Knowledge-Based Economy, ed. WM Cohen, SA Merrill. Washington, DC: National Academies Press, pp. 285-340 
Williams HL. 2010. Intellectual Property Rights and Innovation: Evidence from the Human Genome. Cambridge, MA: NBER Working Paper No. w16213

WIPO (World Intellectual Property Organization). 2007. Patent statistics, available at http://www.wipo.int/ipstats/en/statistics/patents/, accessed 3 December 2007

Wright BD. 1983. The economics of invention incentives: patents, prizes, and research contracts. American Economic Review 73: 691-707

Yamaguchi I, Nagaoka S. 2008. Complementary Reforms of Patent Examination Request System in Japan. Tokyo, Japan: Hitotsubashi University Hermes-IR Technical Report No. 2008-12

Ziedonis RH. 2004. Don't fence me in: fragmented markets for technology and the patent acquisition strategies of firms. Management Science 50: 804-820 